\title{
Project governance and portfolio management in government digitalization
}

\author{
Teemu Mikael Lappi, Kirsi Aaltonen and Jaakko Kujala \\ Department of Industrial Engineering and Management, \\ University of Oulu, Oulu, Finland
}

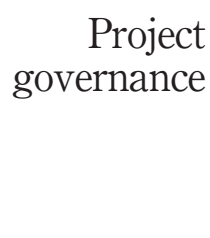

159

Received 6 November 2018 Revised 25 February 2019 9 May 2019 Accepted 10 May 2019

\begin{abstract}
Purpose - This paper aims to increase the current understanding of the connection between operational level information and communication technology (ICT) projects and national level digital transformation by researching how project governance structures and practices are applied in an e-government context.

Design/methodology/approach - An elaborative qualitative study through public documentary analysis and empirical multi-case research on Finnish central government is used.

Findings - The study constructs a multi-level governance structure with three main functions and applies this in an empirical setting. The results also describe how different governance practices and processes, focusing on project portfolio management, are applied vertically across different organizational levels to connect the ICT projects with the national digitalization strategy.

Originality/value - This study integrates project governance and portfolio management knowledge into public sector digitalization, thus contributing to project management, e-government and ICT research streams by improving the current understanding on the governance of ICT projects as part of a larger-scale digitalization. This study also highlights perceived gaps between current governance practices and provides implications to managers and practitioners working in the field to address these gaps.
\end{abstract}

Keywords Project governance, Public sector, ICT project, e-government, Digitalization, Project portfolio management

Paper type Research paper

\section{Introduction}

Digital transformation, or digitalization, is one of the global megatrends that drive private and public sector - organizations' reforms through the adoption of information and communication technology (ICT) solutions to optimize operations and provide better services to customers - or citizens. Digitalization challenges institutions' and individuals' technological, organizational and cultural mindsets and capabilities, which can be a struggle especially in the public sector, as governments have to also cope with legal, political and public accountability-related issues while aiming towards national level digitalization, or "e-government" (Cordella and Tempini, 2015). However, understanding of the impact of processes behind this reformation connecting different government levels - the strategic

(C) Teemu Mikael Lappi, Kirsi Aaltonen and Jaakko Kujala. Published by Emerald Publishing Limited. This article is published under the Creative Commons Attribution (CC BY 4.0) licence. Anyone may reproduce, distribute, translate and create derivative works of this article (for both commercial and noncommercial purposes), subject to full attribution to the original publication and authors. The full terms of this licence may be seen at $\mathrm{http} / /$ creativecommons.org/licenses/by/4.0/ legalcode 
governance level (e.g. government, parliament), the middle executive level (e.g. ministries, agencies) and the operational (ICT project) level - is limited. Hence, more exploratory, empirical research is called for (Snead and Wright, 2014). Even though Finland has been recognized internationally as one of the most advanced e-government countries (OECD, 2015), the ICT development projects keep struggling also in Finland. These struggles are due to complexities and uncertainties in related issues, such as governance, organizing and technology (Omar et al., 2017; Walser, 2013).

Public sector digitalization, like any strategic transformation process, is executed eventually through ICT projects (Anthopoulos and Fitsilis, 2014; McElroy, 1996), ranging from a simple agency-specific online portal to vast, multi-organizational operations management systems. In both digitalization and ICT project perspectives, it is essential to connect the projects with digitalization strategy by ensuring that the project objectives are correctly aimed and properly conducted. In other words, one must ensure that digitalization and associated ICT projects are governed appropriately (Crawford and Helm, 2009; Marnewick and Labuschagne, 2011). One technique to govern projects is project portfolio management (PPM) - a mechanism that on the management level consolidates a group of projects into one entity to ensure the strategic contribution and fit of the projects and maximize the value of the whole portfolio (Kaiser et al., 2015; Meskendahl, 2010; Müller, 2009). Though there have been some contextual studies on PPM application in regional governments level (Hansen and Kræmmergaard, 2013; Nielsen and Pedersen, 2014), knowledge of the topic in e-government context is still limited. Furthermore, the vertical processes between different central or state government levels, and how PPM can be applied to facilitate these processes and the governance of ICT projects, must be researched (Jenner, 2010; Snead and Wright, 2014). The Finnish Ministry of Finance (VM) introduced PPM in 2012 to consolidate central government ICT projects, but its impact and utilization have not been analyzed properly, further empirically motivating this study.

This study aims to improve understanding of the connection between operational level ICT projects performed by government agencies and the national level digital transformation by researching how project governance structures and practices, especially PPM, are applied in an e-government setting. Through explorative public documentary analysis and empirical multi-case research on Finnish central government, this study describes the governance structure for digitalization and ICT projects and analyzes how different practices and processes, namely, PPM, are applied vertically across different levels to facilitate project governance. To better achieve this purpose, two explicit research questions $(\mathrm{RQ})$ were formed:

$R Q 1$. What kind of governance structure is applied to ICT projects in public sector digitalization?

RQ2. How can PPM facilitate the governance of ICT projects vertically across different levels?

This study integrates project governance and portfolio management knowledge into public sector digitalization context, thus contributing to project management, e-government and ICT research by improving understanding of the governance of ICT projects as part of a larger scale digitalization. By describing and analyzing practices related to the governance of ICT projects, this study provides implications for managers and practitioners working in the field. This paper includes a review of applicable literature on e-government, governance and PPM, followed by the research and methodology of this study and the results and discussion, with suggestions for further research. 


\section{Theoretical background}

\subsection{Public sector digitalization and e-government}

Public administrations across the world have been striving towards digitalization, enabled by rapidly evolving technology and motivated by cost-efficiency and quality. This transformation mostly centers around developing and applying digital solutions to streamline internal and external processes and providing better services for citizens (Asgarkhani, 2005; Fishenden and Thompson, 2013; Janowski, 2015). However, to fully use the potential of digital solutions and services, public sector strategies, structures and organizations need to reform accordingly to support renewed solutions and services. This combination has been commonly referred to as e-government (Layne and Lee, 2001; Lee, 2010), and it is achieved through a transformation process that consists of phases from strategy formation to project execution (Anthopoulos and Fitsilis, 2014; Pedersen, 2018). E-government has strong citizen value and collaboration perspectives, thus sharing common ground with preceding public reformation initiatives, such as the market-lead New Public Management (NPM) (Arnaboldi et al., 2004) or coordination encouraging Joined-up Government (Cordella and Bonina, 2012). Though the etymology of "e-government" has somewhat suffered from inflation and been complemented with more generic and ambiguous terms, e-government is still widely used to assess the maturity of ongoing digitalization and to benchmark and provide guidelines for future efforts (OECD, 2015; Rorissa et al., 2011; Valdés et al., 2011). The purpose of e-government or public sector digitalization is not only to provide information and services to citizens but also to create strategic connections internally and externally between government layers and agencies, enterprises and citizens. However, digitalization is challenging in many ways (Pedersen, 2018) and may cause resistance, as it requires significant organizational and technological adjustments, such as architecture adoption (Irani, 2005). The primary reasons for e-government struggles include ambiguous mission statements and poor project management (scope, schedule, stakeholders) causing, for example, resource overuse, longer time to market and unmet client expectations, but there are also governance-related remedies to counter these challenges (Altameem et al., 2006; Kathuria et al., 2007).

\subsection{Project governance}

Governance is a function of management for establishing policies to oversee the work - and ensure the viability - of an organization. It is a rather ambiguous term that has been perhaps most efficiently defined by McGrath and Whitty in their review article from 2015 as follows: "the system by which an entity is directed and controlled" (p. 774).

Furthermore, from organizational perspective, governance defines the structures used by the organization, allocating rights and responsibilities within those structures, and requiring assurance that management is operating effectively and properly within the defined structures (Too and Weaver, 2013). Governance takes place on different levels of an organization that are most commonly divided into three (Loorbach, 2010; Kathuria et al., 2007; Too and Weaver, 2013): the highest level - the strategic, corporate or board of directors and governance system; the middle level - tactical, business or executive and management system; and the lowest level of functional, or operational project delivery system activities. A governance structure is essentially a framework describing the functional roles and responsibilities of these levels within an organizational system, while also identifying the links between them needed for effective and efficient execution (Müller, 2009).

Project governance exists within the corporate governance framework and comprises the value system, responsibilities, processes and policies that allow projects to achieve organizational objectives and foster implementation beneficial to stakeholders and 
the organization itself (Müller, 2009; Turner, 2006). However, the temporary nature of project organizations separates the governance of project organization from that of a permanent organization (Lundin et al., 1995; McGrath and Whitty, 2015). Project governance is a multidimensional concept: it takes place in all levels within an organization by shifting the scope and objectives between (Biesenthal and Wilden, 2014; Brunet, 2018), outside the organization and project through stakeholders and networks (DeFillippi and Sydow, 2016; Ruuska et al., 2011; Winch, 2014), and also a process with the project life cycle (Samset and Volden, 2016; Sanderson, 2012; Stewart, 2008). Project governance creates a decision-making framework for project organizations to execute projects (Joslin and Müller, 2016a; Oakes, 2008). In other words, to ensure that organizations efficiently "Do the projects right." Besides the how, another important aspect governance of projects is the what, i.e. to ensure that organizations effectively "Do the right projects" (McGrath and Whitty, 2015; Müller, 2009). To assure that a project contributes to an organization's strategic objectives, one must constantly align, revise and communicate long-term and short-term project goals and use motivation and control to make performances comply with goals (Hrebiniak and Joyce, 1984; Srivannaboon and Milosevic, 2006).

\subsection{Project portfolio management}

PPM is a project management technique used to align and control a group of projects according to the objectives and benefits of an organization. There are three central objectives for PPM: strategic alignment (ensure strategic direction of projects); balancing across projects (in terms of strategically important parameters, such as resources or risks); and value maximization (in terms of company objectives) (Martinsuo and Lehtonen, 2007; Petro and Gardiner, 2015). Meskendahl (2010) complements these objectives by adding the use of synergies (reduce double work and enhance utilization regarding technologies, marketing, knowledge and resources) to the list. In practice, the managerial activities related to PPM are the initial screening, evaluation and prioritization of project proposals; the concurrent evaluation and reprioritization of individual projects; and the allocation and reallocation of shared resources (Blichfeldt and Eskerod, 2008; Jonas, 2010). These managerial practices are conducted through decisions by portfolio owners and managers at certain process gates or portfolio management board meetings and must balance a multitude of conflicting goals within an organization. PPM therefore attempts to answer project-related questions such as: "What should we take on? What should be terminated? What is possible? What is needed (Dye and Pennypacker, 1999)?"

With regard to ICT projects, the technological alignment through enterprise architecture and standardized processes and software tools can be applied to PPM (de Reyck et al., 2005). However, in the public sector, both ICT PPM and project performance can be diminished with rigid decision-making processes, excess requirements of conformity, communication issues and strong organizational regulations (Mosavi, 2014; Walser, 2013). These political aspects, if integrated into existing decision-making and corporate management practices to avoid excess bureaucracy, can be reversed to strengthen PPM (Martinsuo and Dietrich, 2002). For example, ICT PPM has been important in managing organizational efforts to digitalize local governments (Hansen and Kræmmergaard, 2013), but in general the trade-off between centralization of power and project autonomy can be considered a prevailing and central challenge in the application of PPM in public sector ICT projects (Kaiser et al., 2015).

\subsection{Synthesis: analysis framework}

To synthesize the reviewed literature, an analysis framework based on the research questions was constructed. Project governance consists of the practices that take place 
through functions within different levels of organizations. The term "practices" encompasses all the different activities, procedures and processes that are applied to align, control and safe-guard the ICT project objectives and performance for the value and strategic targets of the organization. Hence, the first part of the framework builds vertically on the multi-level governance structures (Too and Weaver, 2013; Kathuria et al., 2007; Loorbach, 2010) and includes the three organizational levels: strategic (the highest), executive (middle management) and operational (project) with distinguished responsibilities and performance scopes. Horizontally the framework consists of the e-government and project governance-related functions (Anthopoulos and Fitsilis, 2014; Irani, 2005) to describe and categorize the types of project governance practices and their subsequent objectives. As the focus of this research is on the application of PPM as a mechanism that connects the ICT projects with the higher level objectives by alignment and assurance, the second part of results describes in more detail the PPM specific goal alignment and performance compliance practices (Müller, 2009; Kaiser et al., 2015; Blichfeldt and Eskerod, 2008) that can be associated with the "requiring assurance" function - or vertical alignment (Hrebiniak and Joyce, 1984) of project governance. Even though PPM does have additional purposes and objectives such as balancing and value maximization, these are not included in the analysis framework as the purpose is not to explore the overall utilization of PPM in e-government.

\section{Research process}

\subsection{Research approach and empirical settings}

A qualitative research strategy built upon gaining an in-depth understanding of the unique empirical setting was considered most suitable for this study (Sarker et al., 2013; Yin, 2013). As studies on PPM and governance in specific contexts have been requested (de Haes and van Grembergen, 2009; Müller et al., 2008), this research applies an inductive, multi-case method to explore and elaborate (Eisenhardt, 1989; Ketokivi and Choi, 2014; Yin, 2013) the practices associated with the governance of ICT projects, and how they are perceived vertically on and between different government levels, in this case, public sector digitalization (Snead and Wright, 2014). The framework presented in Figure 1 was used in the inductive analysis. The purpose of this study was not to test the completeness of the proposed framework but to use it as a guide to synchronize the analysis and interpretation

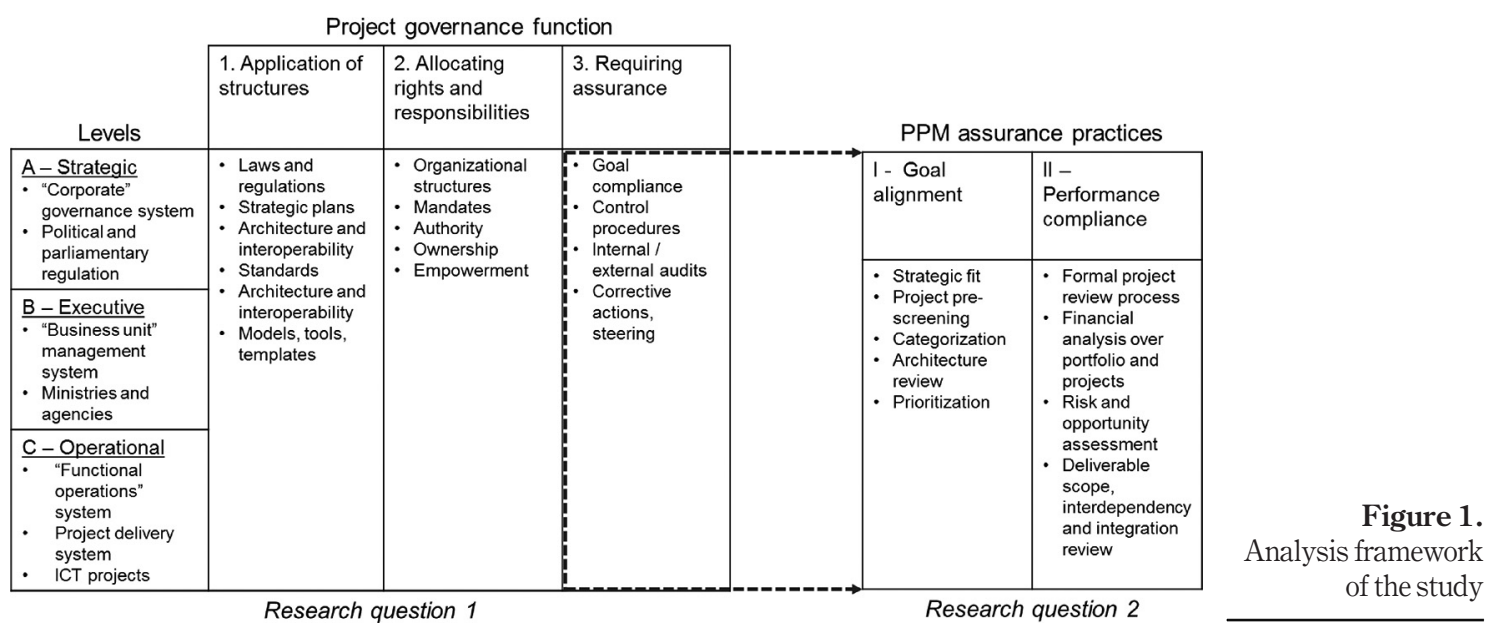


TG

13,2

164
Figure 2.

Finnish public administration chart and research focus of the empirical data among researchers, and as a lens through which the elaboration and refining of the findings with the selected theoretical approaches were processed (Ketokivi and Choi, 2014).

The digitalization of the Finnish public sector is observed through publicly available documentation and four case organizations and projects, described in detail below. The context and setting can provide many research opportunities; therefore, to improve the scope and contribution, some limitations have been made. The study does not focus on the, admittedly important, formation, content or consensus of digitalization strategy (Bowman and Ambrosini, 1997), the horizontal alignment between organizations (Kathuria et al., 2007), or the alignment between ICT and business functions within organizations (de Haes and van Grembergen, 2009; Papp, 1999) and is empirically limited to the central government, as depicted in Figure 2.

Since the 1980s, Finland has, through the introduction of everyday digital solutions such as mobile phones, steadily driven toward digitalization, led by the VM. Recently, as with many other nations and public administrations, digitalization is characterized by global phenomena, such as artificial intelligence, data security, availability and analytics and virtual reality. The digitalization of the Finnish public sector has focused on providing customer-centric electronic services and establishing platforms and infrastructures, such as national service architecture. Though Finland has managed to perform well in international comparisons of digitalization and e-government (Vainio et al., 2017), there has also been criticism from external parties about the governance, efficiency, and strategy of the digitalization (OECD, 2015). VM introduced PPM in 2012 to consolidate and align ongoing and coming ICT projects, but its utilization and application are still ambiguous.

The four cases selected for research:

(1) VM's Public ICT Department (JulkICT), as the main governance authority of Finnish public sector digitalization, represents the strategic and executive levels. Under VM, the national architecture program (KaPA) was selected to represent the operational level.

(2) VM's tax administration (VERO) is responsible for the assessment and collection of taxes for individuals and corporations and providing guidance and service in associated matters. From VERO, a product-based implementation project was selected to represent the executive and operational levels.

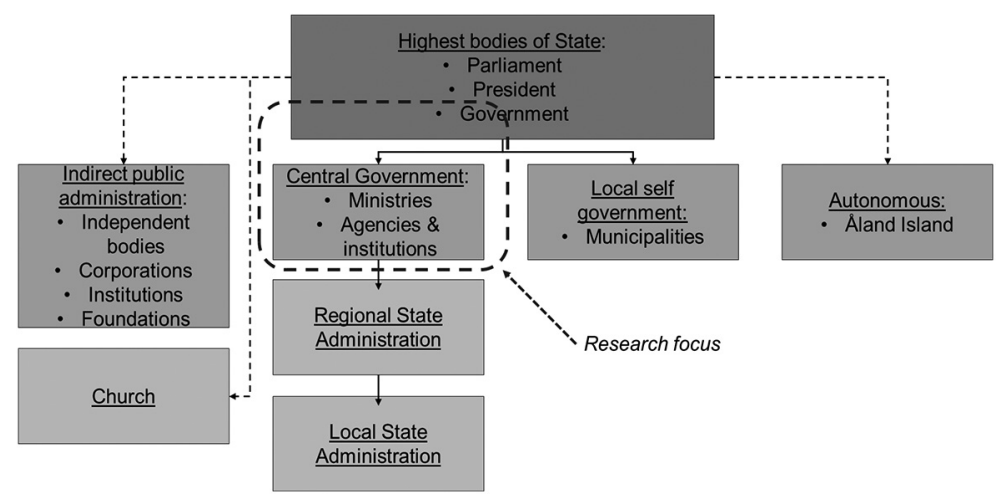


(3) The Ministry of Agriculture and Forestry's National Land Survey of Finland (MML), is responsible for map data material and land surveying, including parceling and reallocating land. MML safeguards land ownership and creditgranting systems by maintaining information. MML has conducted two agile development projects, aiming to digitalize real-time map information utilization, included in the research for executive and operational level insight.

(4) The Finnish Transportation Agency (LIVI), under the Ministry of Transportation and Communications, is responsible for roads, railways, waterways, and the development of the Finnish transport system. LIVI started its first known ICT alliance project in 2016, which was selected to represent the executive and operational levels.

The cases were chosen to provide the most heterogeneous perspective on the project level possible. The availability of data and support material, and the timeliness of the cases especially the LIVI case - were also considered. Additional information about other organizations, projects and programs was provided through public documentation, such as national audit committee reports examining the governance practices in different ministries (e.g. the Ministry of Labor and Economy), and in selected programs and projects.

\subsection{Data acquisition and analysis}

The acquired data consists of three main categories: case-specific empirical data collected by the authors $(R Q 1, R Q 2)$; public documentation related directly to digitalization, governance and projects $(R Q 1)$; public documentation indirectly related to the topic $(R Q 1)$. Supporting the qualitative research agenda, eleven semi-structured interviews with open-ended questions were conducted between 2015 and 2017 to provide in-depth descriptive input from respondents. The respondents were carefully selected from each case due to their knowledge and competence on the subject matter as they were either owners of or key stakeholders in their respective projects. The respondents also held senior managerial or specialist positions in different levels of their organizations, thus supporting the level-based dichotomy applied in this study. Further information could have been acquired by interviewing also the managing executives, team members, or other project stakeholders, but as the additional material provided already extensive amount of objective, supporting data, this was not seen mandatory. The interviews focused on the practices within the organization, projects associated with the governance of digitalization and ICT projects and the use of PPM. The interviews were documented and accompanied by rich supporting material from the interviewees. The interview documents were examined between researchers to interpret the findings and to reduce personal biases. The first category of public documentation consisted of laws, decrees, instructions, manuals, guidelines and tools and templates directly associated with digitalization and ICT projects. The second category included different reports, reviews and benchmarking guidelines providing insight into the topic. Over 1,500 pages of public documentation were acquired from public administration websites and other public data repositories. The details of the research data are provided in Appendix.

The data analysis began with thoroughly reading the materials and constructing rough case descriptions with interesting findings and themes. Then the raw data were imported and categorized in NVivo software. The coding criteria and interpretation rules for the project governance practices were drawn from the analysis framework, initially reviewed and agreed upon, and updated throughout the process among the researchers. The governance structure analysis (RQ1) was conducted in two parts: public documentation (Categories 2 and 3 in Appendix), and empirical case documents (Category 1) to provide rich, 
within-case insights. Both datasets were analyzed in two phases. First, the evidence of practices was reviewed and coded against the theoretical lens to determine the appropriate governance function. In the second phase, the applicable organizational levels of the coded practices were determined. Finally, the results of the coded findings were iterated among researchers to construct aggregated practices per organizational level under each framework dimension. A similar process was then applied for PPM practices $(R Q 2)$ in different organizational levels in the empirical cases and PPM-related public documentation (Category 1 and 2).

The findings - the project governance structure $(R Q 1)$ and PPM-related assurance practices $(R Q 2)$ - are presented in the Section 4, complemented by within and cross-case analyses. Evidence supporting the reliability of the research, presented in the accompanying tables, refers to data in Appendix by stating the category and index; for example, [2.1] refers to the first item in Category 2 ("Act on Information Management Governance in Public Administration").

\section{Results}

As the research aim and questions imply, the results describe the perceived governance structure and PPM practices in two respective sections. The governance subsection explores and aggregates the digitalization and project governance practices, as shown in Tables I and II. The elaboration of the found practices is conducted according to the earlier introduced theoretical lens (Figure 1), and it elaborates the perceived commonalities, peculiarities and gaps within and between governance functions and different organizational levels. Similarly, the following PPM analysis explores and aggregates the findings on PPM practices related to assurance from the empirical cases and public documents, as seen in Table III.

The most interesting finding is evidence in the public documents on the "should be" practices, such as laws, regulations, decrees and instructions, and an equal amount of evidence, coming mostly from the empirical cases, on the "are not" - practices that are not in place or have failed, such as audit reports pointing out the lack of control or structural complexities. This discrepancy somewhat restricted the analysis of what actually takes place and the possibility of drawing explicit implications on how practices affect governance. Hence, it would have been almost tempting to deduce propositions through negative assertions (Johnson-Laird, 1999), but a critically realistic inductive analysis was still applied.

\subsection{Governance structure of information and communication technology projects in digitalization}

The primary objectives for public sector digilization in Finland are set through government agendas and high-level proclamations about general principles. These goals were not well connected to levels below, as all administrative sectors (ministries and the agencies under them) should create their own strategies, which they have already been doing for some time. The most concrete objective mentioned in the digitalization guidelines is "to ensure that digital services are prioritized", which is difficult to measure. The same document also emphasizes the characteristic difference between governing digitalization and public sector administration. The former requires a cross-administrative, process-oriented approach to meet the central purpose of providing better services to citizens more efficiently, whereas the latter is based on regulatory, organizational and financial procedures that are limited by hierarchal and jurisdictive settings. 


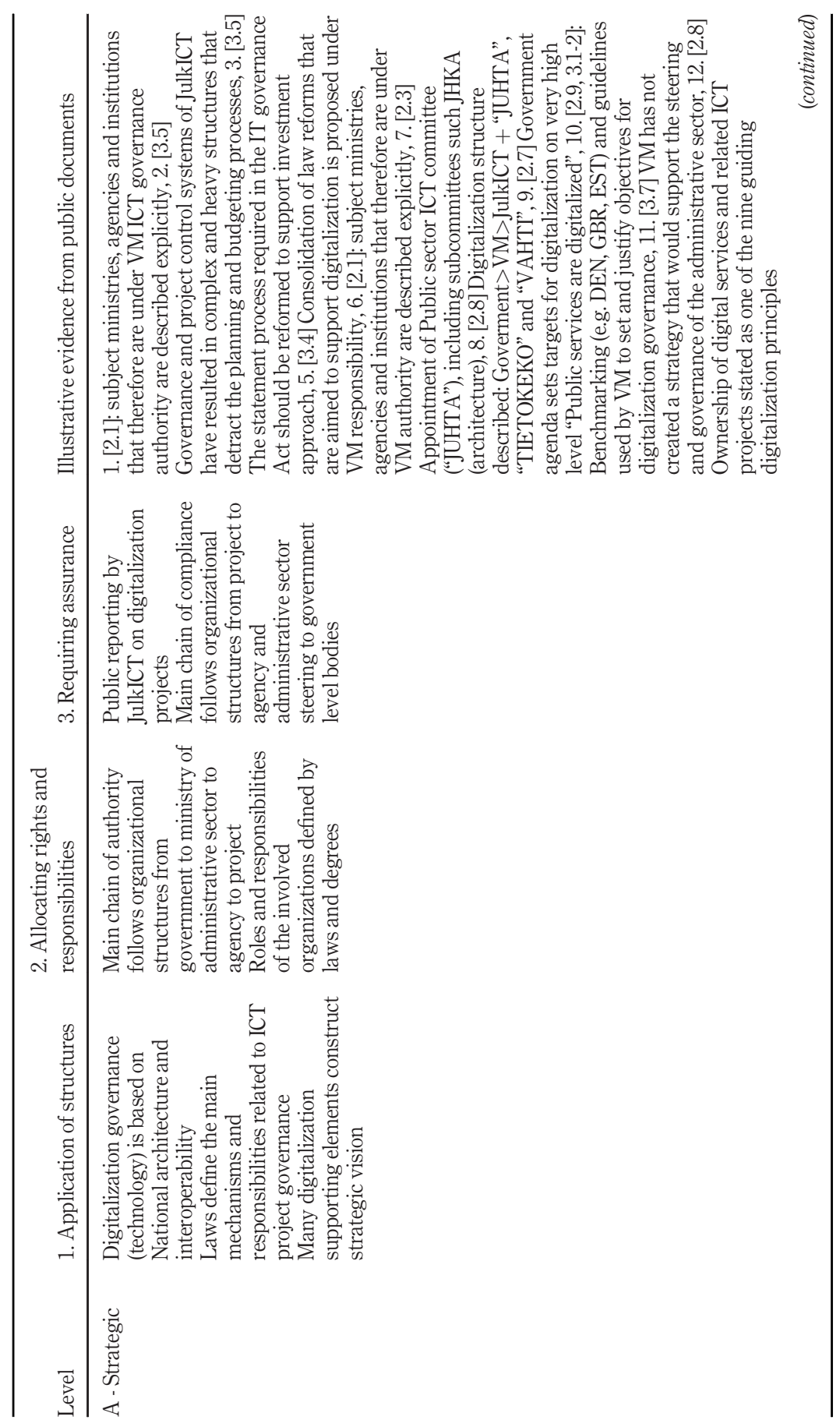

Table I.

Governance structure, public document analysis 
TG

168

Table I.

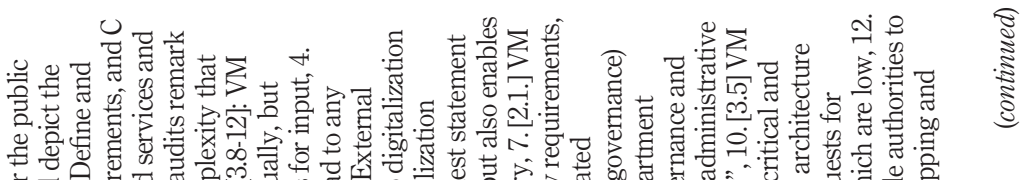

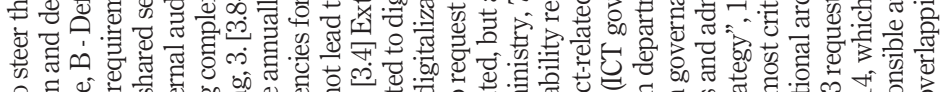

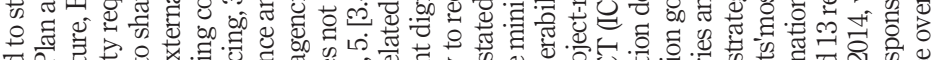

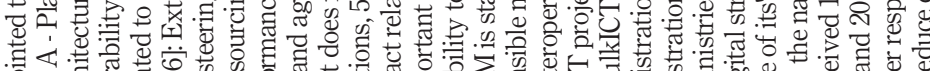

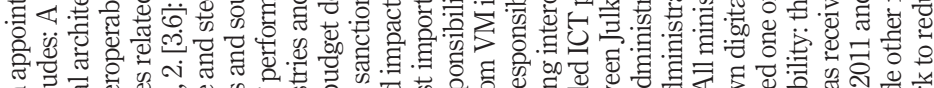

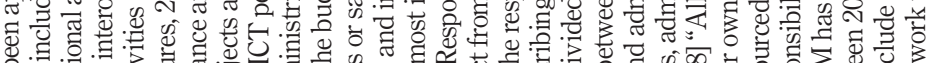

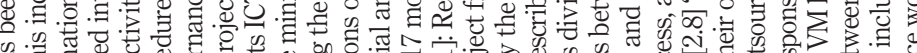

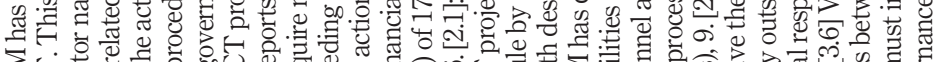

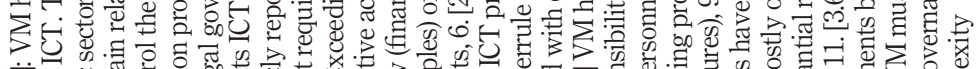

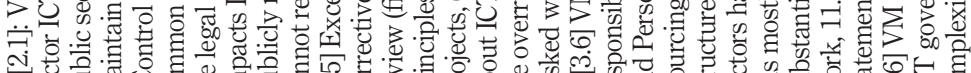

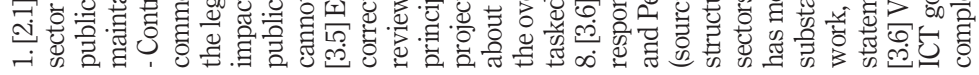

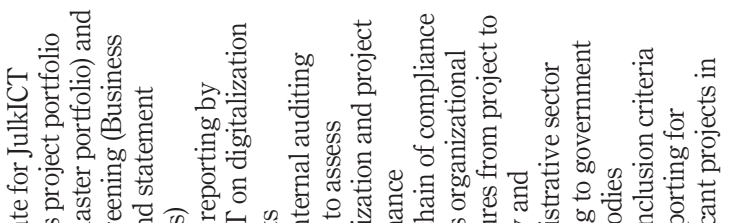

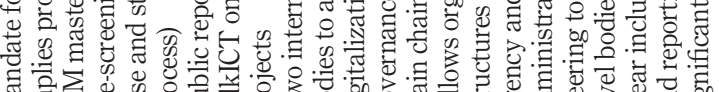

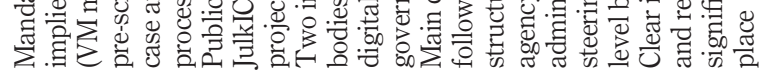

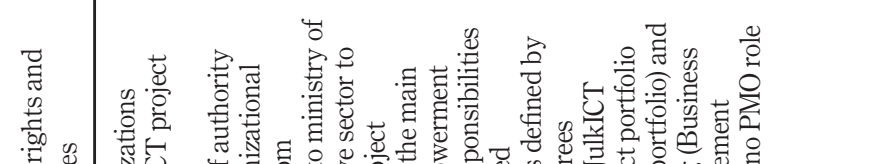




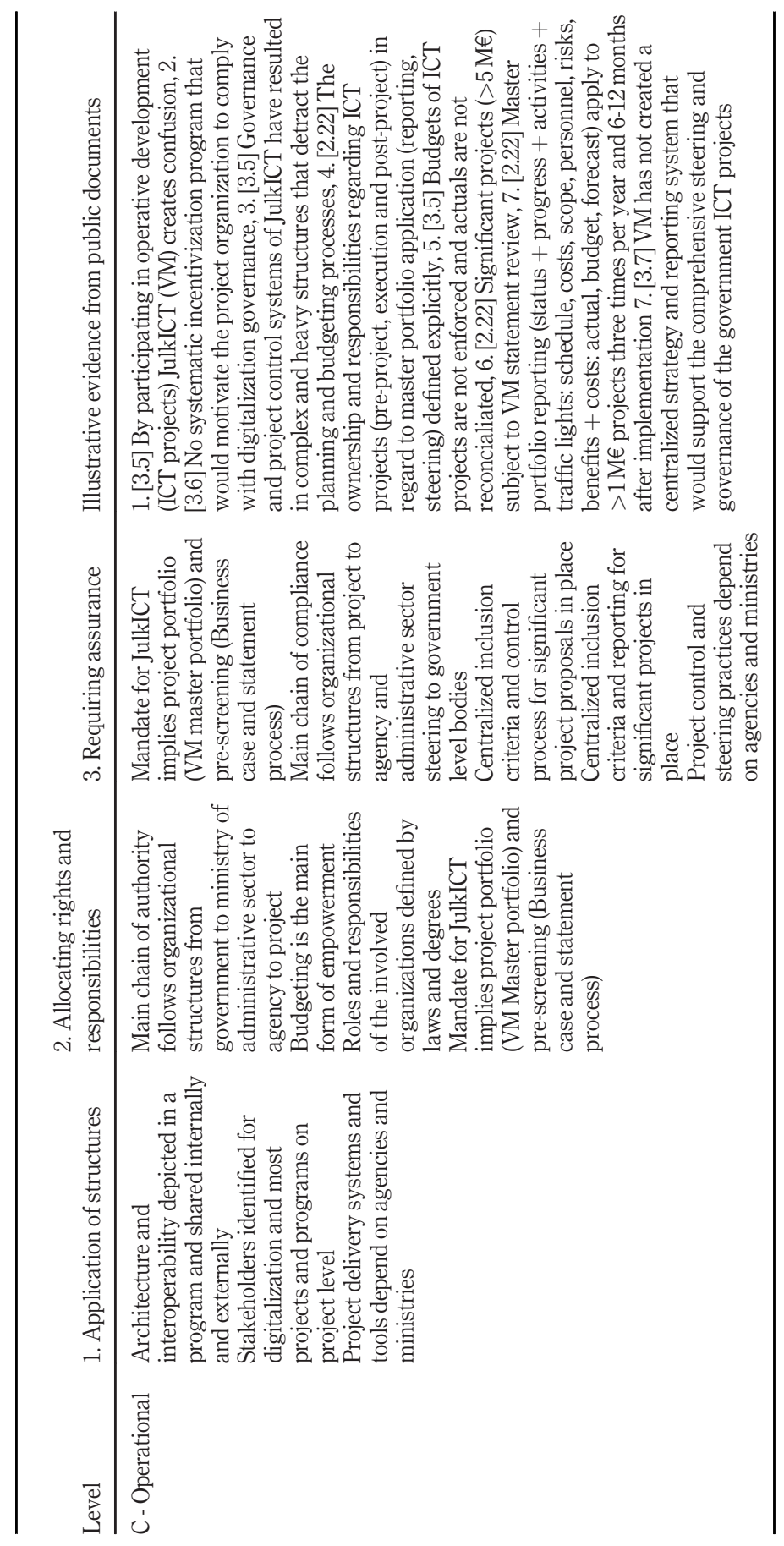


TG
13,2

170

Table II.

Governance

structure, empirical case analysis

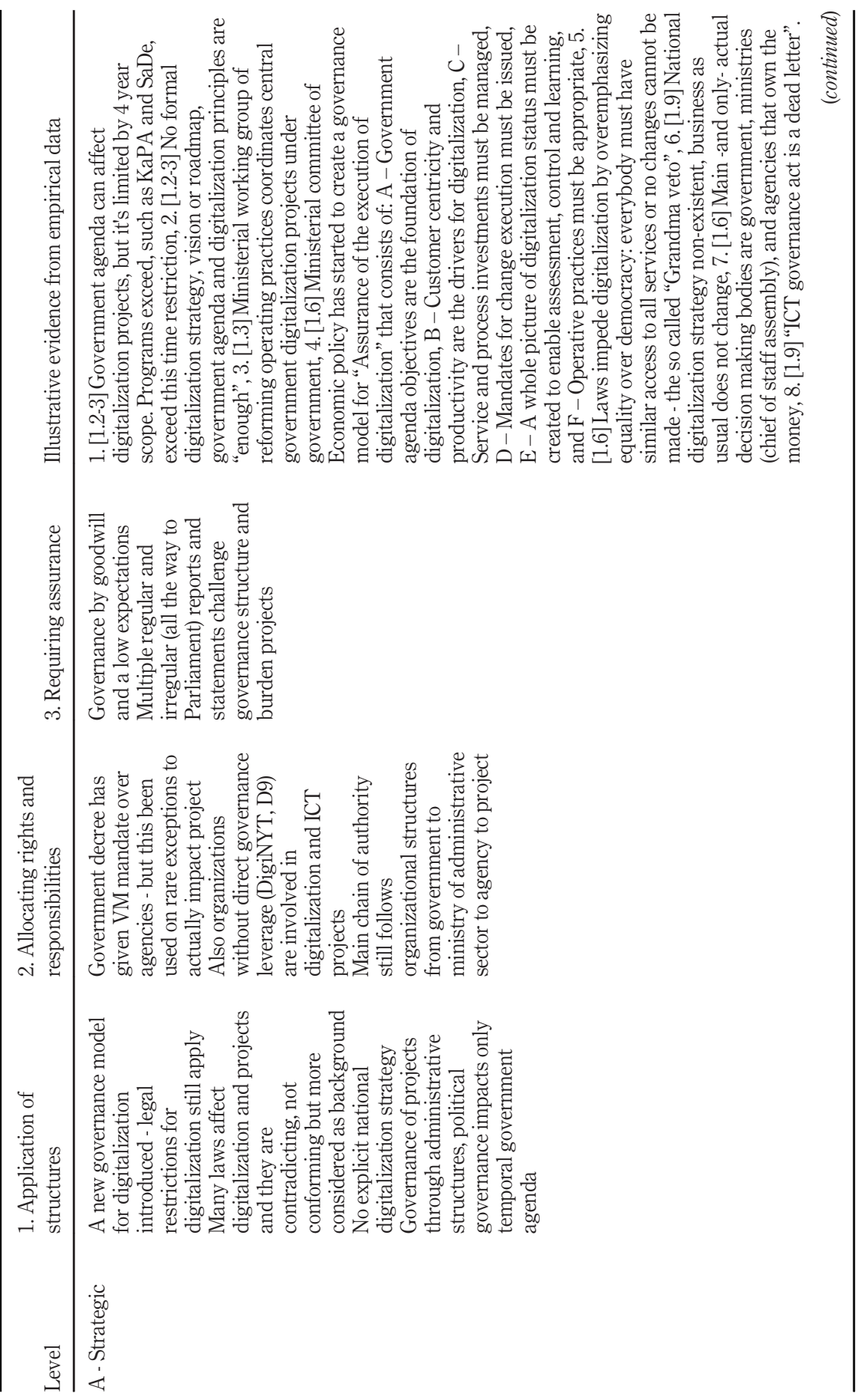




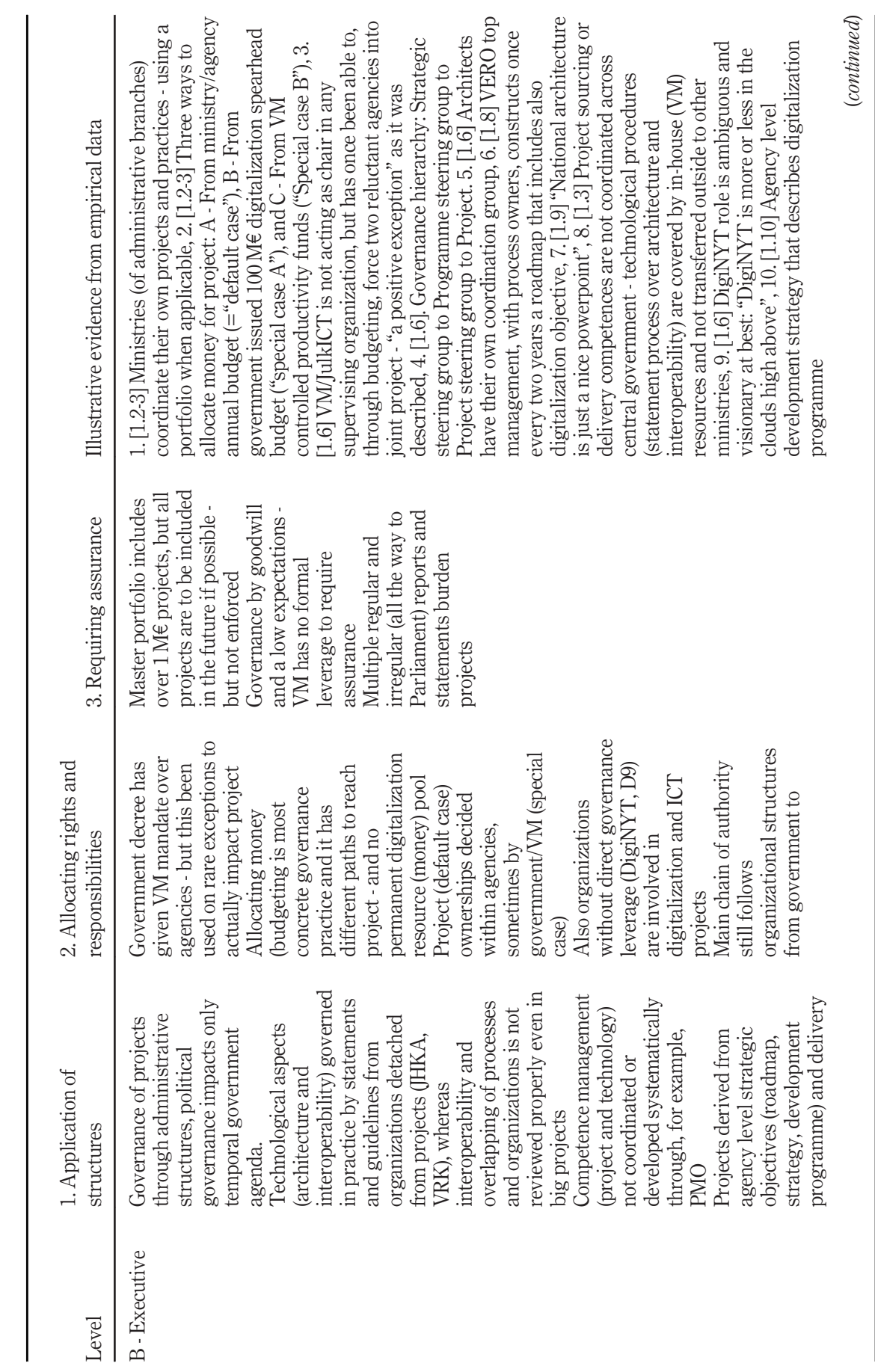

Project
governance

171

Table II. 


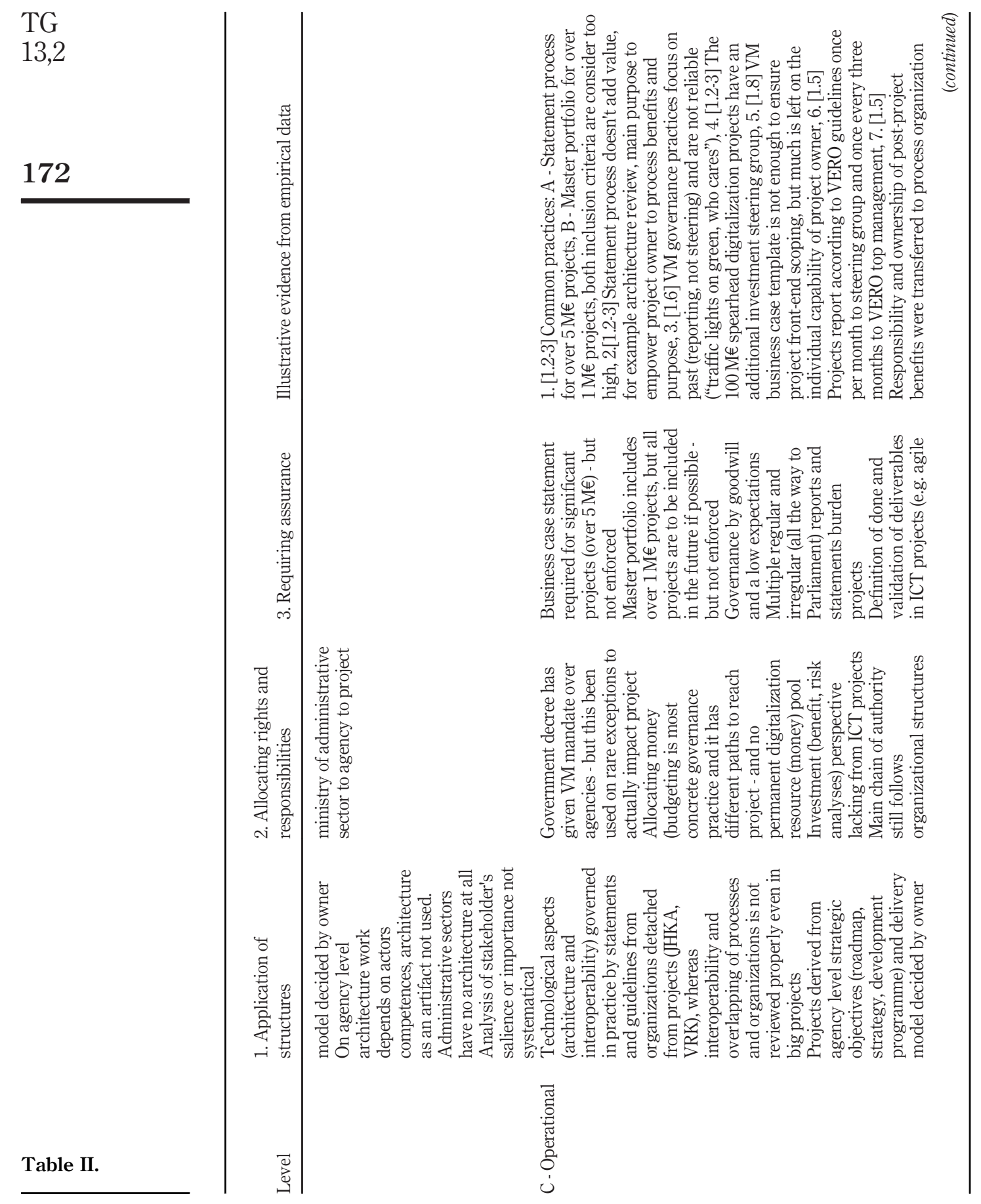




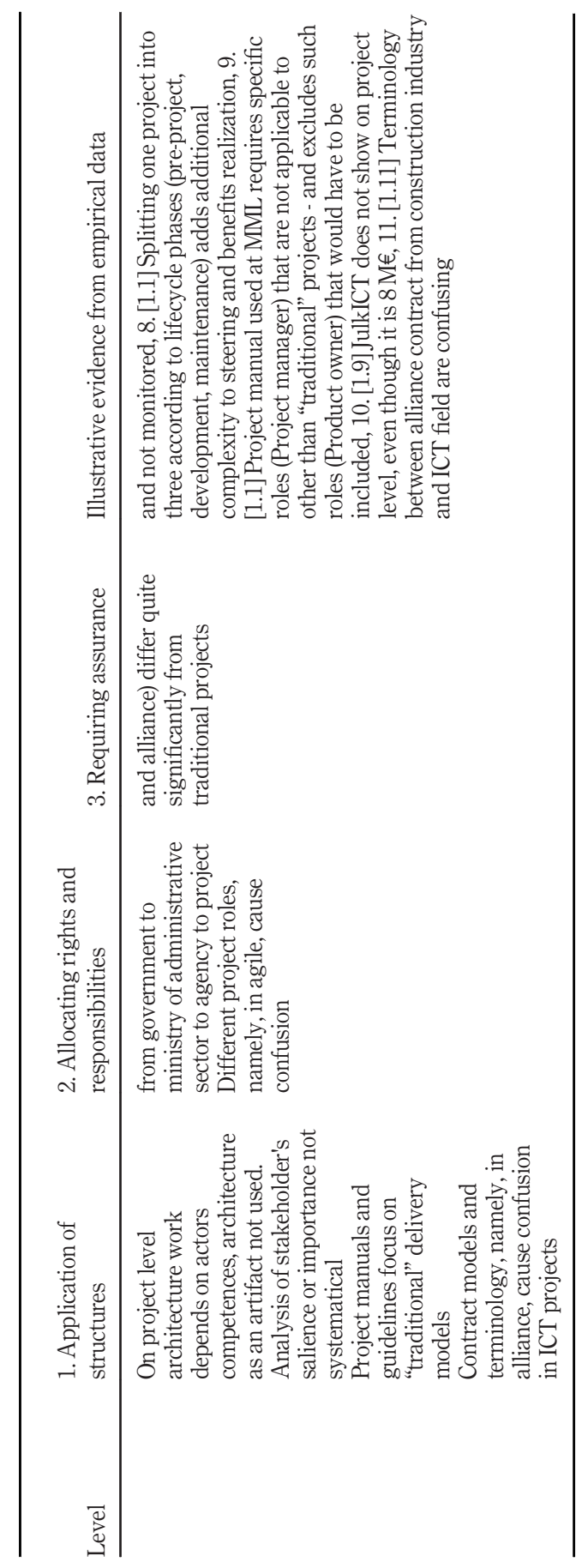


TG
13,2

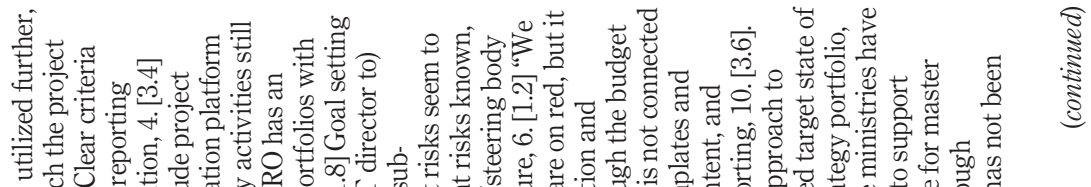

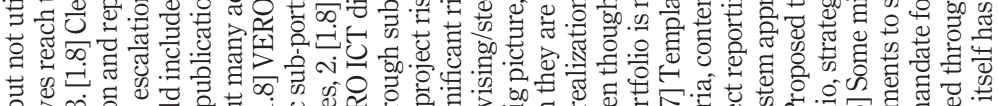

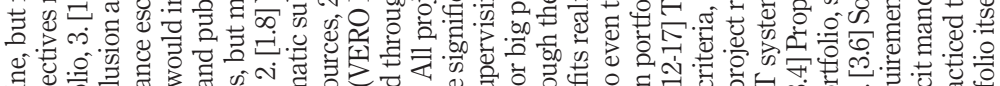

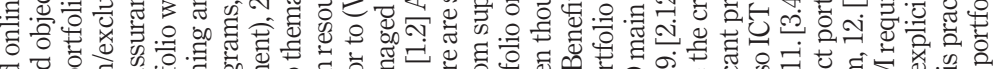

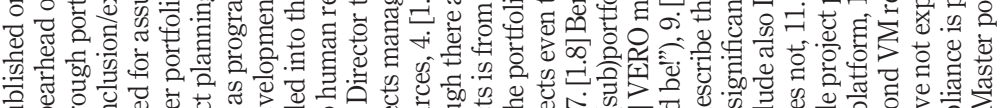

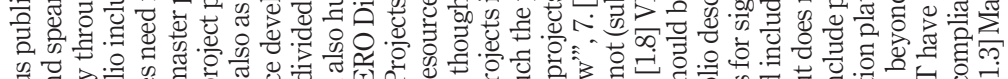
m

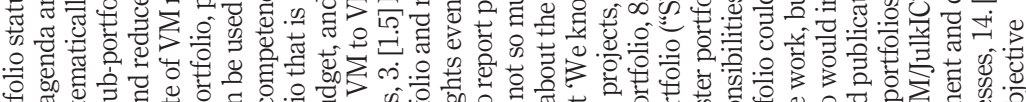

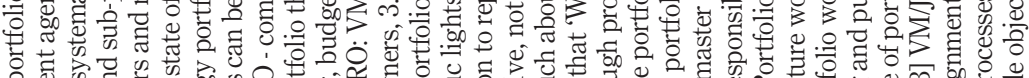

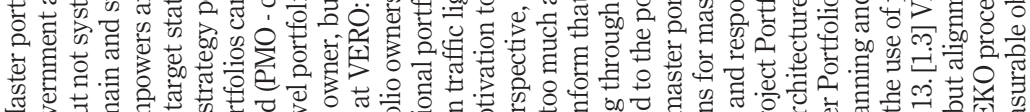

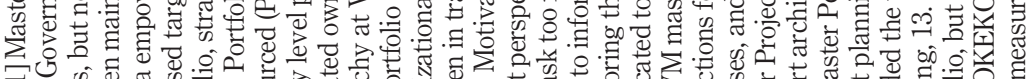

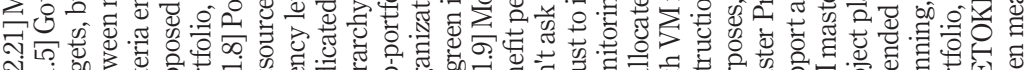

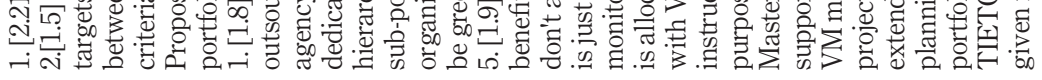

Table III.

PPM Assurance practices

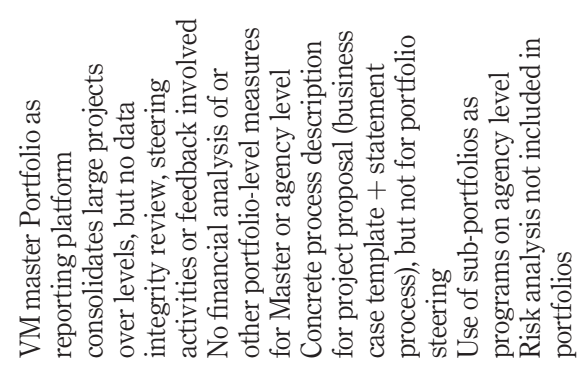

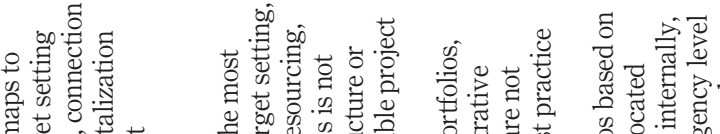

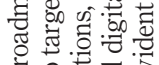

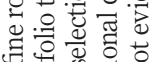

을

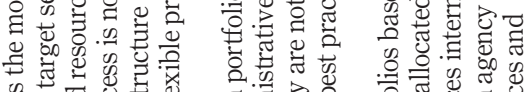

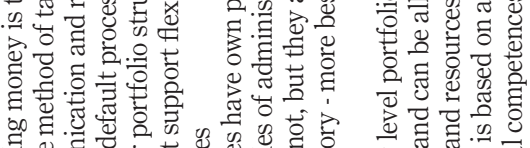
on

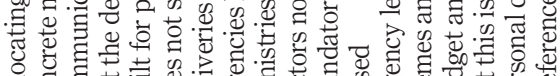

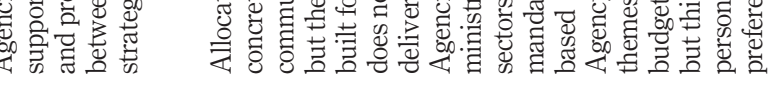




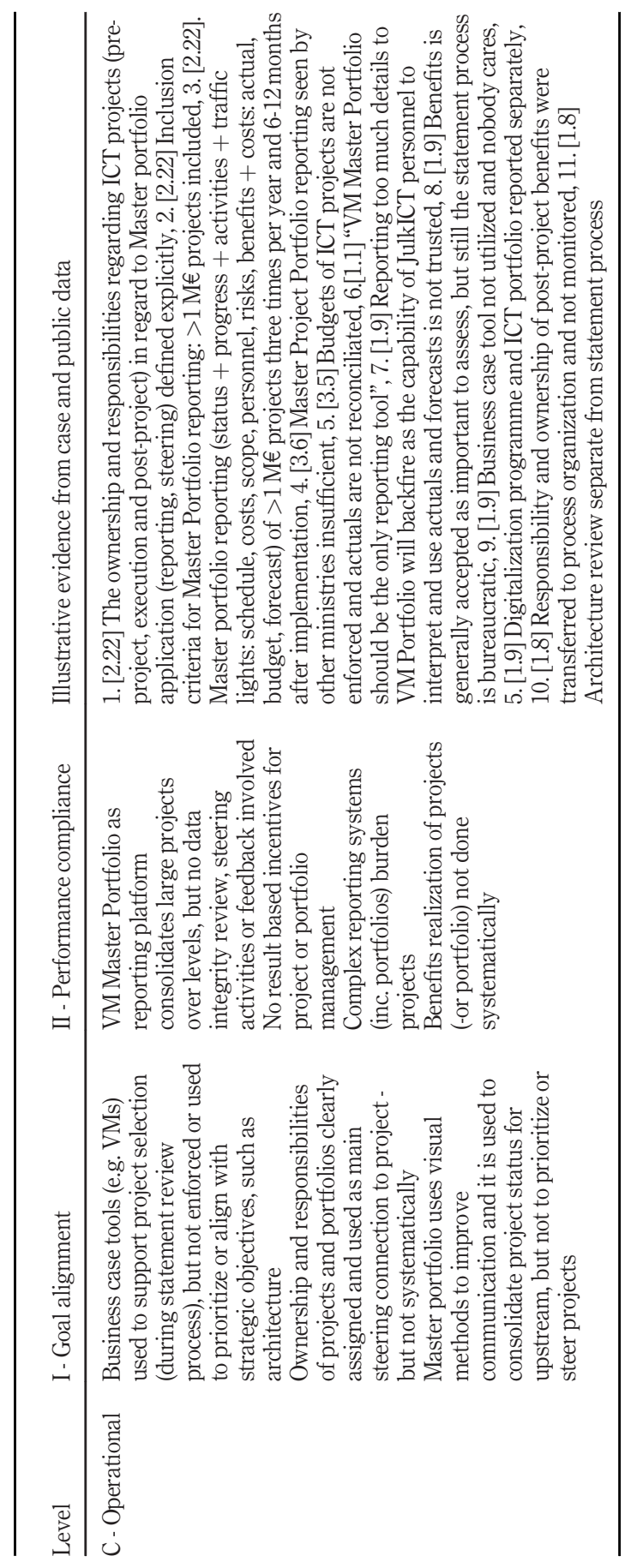

Project
governance

175

Table III. 
As Table I suggests, laws are considered central governance mechanisms, especially in Finland (where obedience is a considered a national virtue), but the terminology used especially in the higher level ICT governance act [2.1] is ambiguous: "follows," "participates," "suggests," "enables" leave room for subjective interpretation. Respondents [1.6] have criticized the particular act: "The biggest challenge in executing the law has been that there is no clear understanding and consensus within the administration about the descriptions and specifications." Multiple overlapping laws and regulations - namely the ICT governance act (ICT-specific, under VM), sourcing act (sourcing process-specific, under the Ministry of Labor and Economy) and administrative sector-specific (for example, social and health) acts - may also create strong tensions and complexity for ICT sourcing and project management and require special competences from the participants and responsible authorities. The general approach is to reform the decrees and laws instead of focusing on the problems related to the processes and compliance, as reported by National Audit Office of Finland (VTV) when describing the status of statement processes related to ICT system sourcing. On the operational level, the main ICT governance act [2.1] is regarded as a "dead letter" with more hype than actions. The national service architecture defines the overall picture of digital infrastructure but does not yield support to an interoperability analysis of project deliverables or support the empowerment of technical and project actors. "It is a nice PowerPoint" [1.10] was a common reference on the project level. ICT projects, sourcing, and systems are also governed by various technical factors, such as recommendations from JUHTA (The Advisory Committee on Information Management in Public Administration) and VAHTI (The Government Information Security Management Board), rendering the ICT development as a separate entity from operative process development, as seen by VTV. Most tangible governance models associated with digitalization and projects are left on the executive level. Project manuals and supporting tools and constructs seem to be agency specific, and no formal consolidation or integration takes place. VM aims to construct an explicit governance model (through the Ministerial Committee of Economic Policy) for digitalization, but the draft model seems to follow the same passive mode as the laws above [1.7].

The main responsibility of public sector digitalization in Finland lies on JulkICT, but in practice, they rarely possess any authority over agencies or projects. Money, namely, budgeting, is the strongest governance practice, and the most concrete way to govern organizations and projects. From a project perspective there are three ways to allocate money: the default, "business as usual" method by allocating funds from the agency's annual budget; the government spearheads projects derived directly from government initiatives (such as KaPA, or VERO's income register project); and the special budgets, namely, the $100 \mathrm{M} €$ one-off digitalization launch pool. A fourth way to gain financial resources is the productivity fund under VM budgeting committee authority, but this is not systematic, as it also involves non-ICT projects. However, on the operational level, like LIVI, the second and third methods are considered more confusing than supporting, as the money cannot provide long-term capabilities, so the "business as usual" method prevails.

At least one document [2.22] clearly described the roles and responsibilities regarding ICT projects: the owner (the ministry of the administrative sector and its sub-agencies) manages the project from pre-project to post-project and is responsible for statement request process, reporting to the master portfolio, and other compliance practices. On operational level, the roles and responsibilities can be determined by tools such as project manuals, which do not, however, well support non-traditional project delivery models or methods, such as agile development or project alliances. All projects and programs have at least one steering group, and the decision-making power and authority for steering groups are from 
organizational (agency) level positions. For example, the KaPA program steering group head could make decisions over the program as he was also the ICT director of VRK. The role of stakeholders was identified at executive and operational levels, as seen in Table II. For example, the hierarchal structure of stakeholders in the SaDE program [3.5] was described as Political decision makers $>$ Developer communities $>$ Early adapters $>$ End users. This structure seems to contradict the customer-centric approach of digitalization strategy. However, though the structural complexity of roles and responsibilities was recognized by respondents, and the general principles wove the simplification of administration and reduction of norms, the activities seemed to lead toward further complexity - as seen in [1.7], where the introduction of an investment approach came with yet another informative steering group (the digitalization investment steering group). Also, organizations without any formal authority or governance authority, namely, the D9 digitalization team and DigiNYT committee, were involved in digitalization and ICT projects. External members from non-governmental organizations and the private sector were included in these two groups, but curiously - and maybe unfortunately - no research institutions were represented. Finally, JulkICT supervision, as stated by VTV, does not affect project or program (SaDE and KaPA) execution, as they are not included in the formal project or program structures.

The assurance requirement is conducted on strategic level mainly through reports and statements by direct supervising bodies such as government and committees under parliament or audit organizations. However, the tone of these statements is passive: "needs to be considered," and the corrective actions are only "proposed" or "suggested" instead of allocated or empowered to specific, responsible authorities. A practical assurance platform for this level, introduced by JulkICT, is the master portfolio aiming to consolidate "most projects $[>1 \mathrm{M} €]$ across central government." This platform, along with the decreemandated statement process for "significant projects" [ $>5 \mathrm{M} €]$ using the VM business case template, includes the only consolidated and shared ICT project assurance practices that reach across levels. JulkICT uses the master portfolio to consolidate status reports for TIETOKEKO, which is the organization coordinating ICT development across the ministries of administrative sectors. TIETOKEKO also receives consolidated reports of ICT projects and, if necessary, makes statements on them but does not conduct any steering activities. Interestingly, JUHTA is not mentioned in this control process description, though it is recognized elsewhere as a significant actor [1.6].

On operational level, assurance equals reporting and documentation, but informal communication is used too. The reporting procedures and structures vary within cases, but all were characterized by complexity: the same or similar information about project and program progress must be reported in multiple directions and irregular intervals. Additionally, as with LIVI, that reporting content plays a role: "Too much information and too many details will backfire." The capability of JulkICT controllers to assess forecasts and benefits and their tendency to anchor themselves with given numbers is perceived as burdensome, seeming to imply issues with data integrity - a fact that JulkICT also recognized, as "The traffic lights are nicely on green all the time" even though there were known issues [1.3]. Generally, the assurance and authority seem to be characterized by goodwill and assumptions. The applied project measurements were agency-specific, not connected with any results-based incentives, nor were there any sanctions from the owner organization, JulkICT, or TIETOKEKO for exceeding a budget. Post-project benefits realization was supposed to be applied systematically but was not, even among the significant projects. 
TG

13,2

178

The segmentation of projects combined with structural complexities made pre- and postproject assessment difficult, as described in the LIVI and MML cases. Finally, different project types require different approaches to assurance as seen in the LIVI and MML cases. However, the formal and rigid assurance processes and procedures do not necessarily support this, which leaves, for example, the agile project level control and steering on "clerical civil disobedience" [1.6]. From a technical perspective, a curious control element is the project's deliverable validation. ICT projects, especially agile ones, as in the MML case, tend to have a vague concept of a deliverable target, so validating and measuring the outcomes against predetermined targets is challenging. Also, as in the LIVI case, the formal compliance processes and structures, namely, project contracts, need to support flexibility and constant acceptance instead of a fixed stage-gate type of process.

To synthesize the current governance of Finnish public sector digitalization and ICT projects, an external audit report [3.7] identified following issues: strategy formation, target setting, reporting, results-based management and the preparation of regulations. This report is consistent with the findings of this study, which also illustrate how the project governance functions - the application of structures, allocation of roles and responsibilities and requiring assurance - have multiple, vague and ambiguous interfaces between elements and levels, and thus yield to the complexity of the governance structure, as described in Figure 3.

\subsection{Project portfolio management assurance requirement practices}

The pre-project business case analysis was conducted in all cases as an initial goal alignment practice, but only the significant projects are subject to a more rigorous JulkICT statement process. The strategy toward which a project's fit is reviewed is in "default" projects the agency's or ministry's own strategy. The national digitalization strategy, which is perceived to be impractically vague, is not introduced or applied. The "special" projects reflect the strategic objectives of the government, as they are derived directly from government initiatives. The statement process and master portfolio have a mixed reception

Figure 3.

Finnish central government digitalization and ICT project governance structure

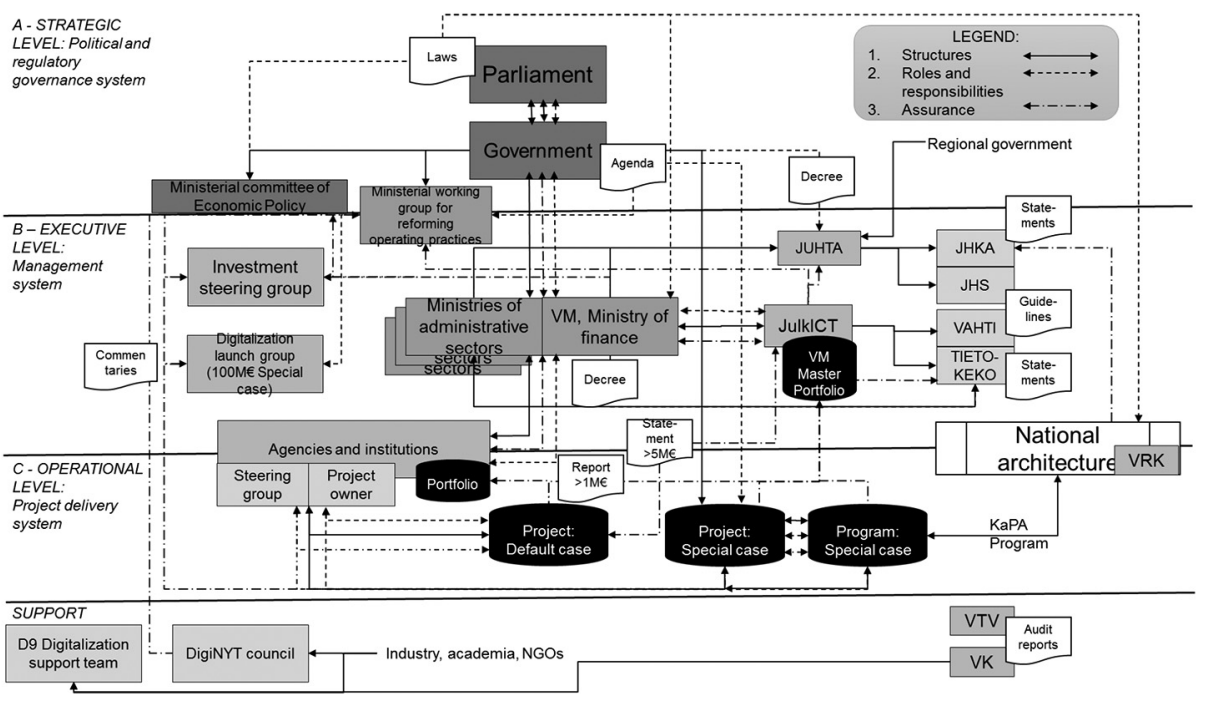


at the operational level, as seen in Table III, where they are considered either unnecessary bureaucracy or the de facto practices.

Architectural review in the business case template is mostly superficial and does not receive a formal review from a dedicated technological authority under JulkICT, though the resources and competence do exist. The master portfolio could be used to prioritize and categorize projects but presently is not, though development initiatives have been taken. At the executive level, the applied portfolios are a good start for goal alignment, but, if accompanied by a roadmap that sets program-like mechanisms, the result is more structured. However, it seems lucrative, especially in digitalization, to focus on luxury items like artificial intelligence, but mandatory, hardware-related issues, namely, legacy systems and infrastructure, cannot be neglected either. Deriving projects merely from the technological trends is not feasible. An important factor regarding goal alignment at the executive level is the allocation of resources, especially budget, directly to the portfolio that empowers the owner and increases motivation and delivery capability. However, increased organizational complexity is an imminent risk if the portfolio also allocates fixed human resources and operative process responsibilities, as for example in VERO's robotics portfolio, turning the portfolio into a new matrix organization. If the portfolio and organizational structures conflict, the governance chain clarity may be endangered. At the operational level, the communication during the prospect phase is actually supported by strict, bureaucratic structures. Project actors can easily determine the responsibilities of administrative sectors and agencies and clearly understand what triggers the inclusion of certain substance specialists. However, this clarity seems to apply only to organizational and administrative aspects, not to the technological or economic sides of pre-project planning. The business case template by VM does not, however, coordinate any formal procedures that would ensure inter-organizational co-operation; it merely asks actors to "describe connections." Therefore, it seems that besides the formal mechanisms, a lot of communication and coordination within and between levels and organizations is left to the individual's responsibility. The pre-project phase can extend over a year if the project owner must ensure all elements that are not included in the business case template but needed to secure all practical and technological aspects.

Performance compliance in PPM includes formal review, control and motivation. The motivation from incentives or rewards encouraging either project-level performance, reporting and compliance, and aligning with higher level objectives through portfolios did not take place in any cases, nor is there a formal process describing it. These practices are based on managerial competences and leadership capabilities within organizations, or, to a very limited extent, the remuneration packages of project-level actors, which in Finnish public sector organizations are quite restricted.

The results indicate that there is a control gap at the executive level. Despite having the highest possible legitimate authority, JulkICT considers themselves mostly a quality control and support mechanism for project- and (master) portfolio-related control activities that "Should take place anyway" [1.2-3, 1.6]. This declaration implies a discrepancy between the understanding of actors' roles and purposes and the mechanisms of digitalization and related ICT projects. As discussed, the control of projects and portfolios are mostly connected to complex reporting and merely informative measurements. Measurements were applied to projects directly or through agency and master portfolios, but there were no consolidated metrics or objectives on any portfolio level. The complexity also characterizes many projects reaching over several areas of organizational responsibility, or, as in the VERO case, the newly introduced sub-portfolio scopes. Besides challenging project ownership, this complexity impedes control by and toward the steering group, consisting of 
process owners and the VERO-level ICT department. However, control is not just about reporting but also includes steering and planning, which do not come from (master) portfolios or the organizations associated with them but from the owner organization's chain of command, i.e. steering group and agency line management. The master portfolio is currently only a visual platform yielding a public consolidation report, not otherwise used for formal review or communication. It does possibly enable planning, balancing and optimizing resources, but only one review report [3.4] recognized and suggested this option. This report also gave explicit suggestions on how to develop a master portfolio toward successful PPM. The master portfolio reformation must consider governance and technical ownership, obligations and motivations for budgeting, the comprehensiveness of most ICT projects, the transparency and confidentiality of information and the consolidation and development of project culture.

\section{Discussion}

In this section, both the project governance and subsequent PPM assurance practices are elaborated through the main organizational levels, the highest strategic, the middle executive and operational project levels. The discussion presents the main empirical findings in respect to the inherent objectives of project governance and PPM on these levels to identify the emerging gaps between findings and current knowledge.

\subsection{Strategic level governance and project portfolio management}

Instead of building a foundation and purpose for digitalization, the results of this study indicate that strategic level governance is dictated by politically driven, abstract digitalization strategy (or a lack thereof) and different laws and regulations are used mostly for legitimization. The biggest gaps identified were related to the content and formation of digitalization strategy. The strategy consists of various intermittent statements and agendas that do not yield a tangible goal statement, obscuring a consensus or shared understanding of the goals and priorities (Bowman and Ambrosini, 1997). This obscurity creates tension between the project and digitalization strategy, as a project is already a temporary organization that should connect with permanent settings rather than a temporary, short-term political ambitions (Jonas, 2010; Lundin et al., 1995). A feasible policy could be to establish a permanent strategy process and a tangible artefact, in which the political impact from temporary government agendas could be used to establish priorities and principles for vision setting, but a process aimed toward a prioritized, scheduled roadmap of digitalization could be sustained over government terms.

In the parliamentary and democratic public sectors, laws are the most evident mechanism for establishing norms and policies at a strategic level. However, the results of this study indicate two imminent, yet even somewhat paradoxical, issues with the laws: some of them legitimize but do not give authority and at the same time many cause governance overlaps. First, as discussed in Section 4.1, the ambiguity and interpretation challenges of the main ICT governance acts cause distractions. Second, the laws applicable to project processes and technological elements tend to be too detailed in Finland, per a respondent in the MML case. Excessive detail leads to a narrower scope for a single law, restricting its applicability and comprehensiveness. For example, digitalization project processes must comply with at least four different laws, depending on the scope of the project. Updating laws is a time-consuming parliamentary process seriously restricting the rapid evolution of digitalization and flexible ICT projects (Lappi and Aaltonen, 2017). It would still be reasonable to revise and reform the applicable laws from governance 
perspective into a comprehensive entity that empowers clearly the responsible authorities, reduces the overlap and leaves the functional details out of legal scope.

The aim of assurance at the strategic level is to derive development plans and prioritized objectives from corporate strategy, based on a shared understanding of common goals (Hrebiniak and Joyce, 1984; Kathuria et al., 2007), establishing a subject for goal alignment. In this research and PPM context, this would mean a portfolio on the highest organizational level that interacts with a strategic roadmap to get and enable prioritized objectives. However, therein lies the most current issue of vertical alignment of this multi-case study: no strategy or roadmap is connected with the existing VM master portfolio. The VM master portfolio could be used more effectively to update digitalization internally and externally to provide improved political and public compliance evidence and communication (Mosavi, 2014). Simultaneously, if the digitalization strategy, roadmap and master portfolio were integrated, the target setting and the connections to lower levels (executive level ministries and agencies) would be more feasible.

\subsection{Executive level governance and project portfolio management}

Based on the empirical findings, the two dominant governance gaps in the executive level could be synthesized into excess amounts of structural complexity, as seen in Figure 3, and an absence of authority. The topic and context itself are so complex that adding structural confusion by adding permanent (D9, DigiNYT) or temporary (Spearhead investment steering group) organizations with an ambiguous purpose and authority will not reduce challenges such as control integrity due to burdensome reporting (Joslin and Müller, 2016a; Walser, 2013). For example, JulkICT's sense of ownership and authority contradicts any ownership perspectives discussed in project governance literature and can restrict decision-making efficiency, especially in ICT projects (Andersen, 2015; Drury et al., 2012; Olsson et al., 2008). The lack of authority has led to the emerging application of goodwill as an assurance approach, which could be mended with law reformation or by streamlining the budget process so that it flows through the ministries and agencies that actually have the legitimacy and power to govern ICT projects. Emphasizing and clarifying ownership structure would also mitigate the prevailing satisfaction for less mentality but would impose a balancing issue between the centralization and decentralization of power (Janssen and van der Voort, 2016). As JulkICT saw, the organizations conducting projects know the best way to manage them. However, the overall digitalization project delivery capability of central government could be managed as a whole even if the execution and substance-specific knowledge were left in the agencies. Shared and common practices related to project delivery, such as sourcing and choosing the appropriate delivery model, could be included in the discussed governance model, under a project management office (PMO), for example (Mosavi, 2014; Unger et al., 2012). Equally important aspects of more central governance are the common technological elements of digitalization and ICT projects, namely, architecture, interoperability and data (Irani, 2005; Janssen and Klievink, 2012).

Executive-level PPM assurance aims to establish a formal review process for the continuous balance and value maximization of a portfolio and prioritizing projects and their resources according to aligned objectives (Müller et al., 2008; de Reyck et al., 2005). Based on the evidence, the capabilities and motivation to achieve these goals exist, but the lack of authority has rendered the VM master portfolio a mere reporting template. This notion resonates with how institutions gain legitimacy, or through what mechanisms central government constitutes power in digitalization (Scott, 2013). To improve this, the JulkICT and master portfolio legitimacy might be worth re-establishing, 
along with the content of the actual portfolio for a more complete picture of all central government ICT projects and sub-portfolios (Project Management Institute, 2013) of different agencies and a formal, stage-gate process (Cooper, 2008) to facilitate the steering and control of portfolios.

\subsection{Operational level governance and project portfolio management} projects is characterized by a low amount of metrics and a high amount of reporting, both by the project managers and by external auditors within the public sector administration. The external audits do not yield any corrective actions if they do not include a motivational element for the project owner, such as sanctions (Müller, 2009). The amount of project documentation and reporting shown in the empirical data is currently both a burden and source of confusion for project managers due to the complex governance structure, a fact that especially detracts from the performance of agile ICT projects (Lappi and Aaltonen, 2017; Nuottila et al., 2016). Different project types, namely, agile, and delivery models, such as alliance, have varying approaches to project deliverables and measurements (Love et al., 2010; Vlietland et al., 2016); therefore, the applied governance structure should recognize and support these models and the established assurance practices. The deliverables also connect to another governance aspect of assurance - the post-project benefits realization (Marnewick, 2016; Serra and Kunc, 2014). According to JulkICT, this aspect is already challenging, as they cannot demand the analyses afterward and have difficulties establishing determinants for the benefit or impact of ICT project results, systems, and services. Benefits cannot be realized if the users, either personnel of public administration or the customers, the citizens, do not use them.

Assurance has a strong motivational aspect (Hrebiniak and Joyce, 1984). Controlling and measuring through portfolios does take place, but it is conducted either at agencylevel portfolios, or in "special" or significant projects, toward the master portfolio. There was no evidence that either of these control modes provided any steering constituting feedback, which partly caused poor motivation among project managers to report properly. In the personal perspective of project and portfolio actors, the application of project and portfolio results-based incentives could support motivation not to mention the possibility of sharing project benefits and risks similar to an alliance model (Lahdenperä, 2012; MacDonald et al., 2012). Finally, an important aspect concerning the operational level assurance through PPM is the selection of projects during pre-screening (Archer and Ghasemzadeh, 1999; Bridges, 1999). Currently, each case organization conducts their project evaluation to the best of their knowledge, applying either the business case tool by VM or some other template. To support the higher, executive-level, portfolio control process, the operational level project evaluation tool and review process could be scaled to fit all project sizes and types, though the formal statement process still applies only to the significant $(>5 \mathrm{~m} €)$ projects.

\section{Conclusions}

This research explored the governance of public sector ICT projects in a complex and high-impact phenomenon - government digitalization. The research describes the project governance and PPM practices of government ICT projects through five thematic focus areas and proposes a three-leveled project governance model for digitalization and ICT projects. This provides the managers and practitioners working in the public sector digitalization context means to better understand how the project 
governance practices impact ICT projects from e-government perspective. By illustrating and elaborating how these practices are conducted on and between different levels within central government organizations, this research provides new understanding on the sought-after vertical process explorations (Snead and Wright, 2014), thus contributing to e-government research. Similarly, project management academics benefit from this research, as it brings a contextual stream into the PPM discussion, which has so far received limited attention (Müller et al., 2008). Prior research on public sector digitalization and e-government transformation has focused primarily on the macro-level, social phenomenon and the factors that enable or distract from the transformation progress (Gil-Garcia and Martinez-Moyano, 2007). Not until recently the connections between the e-government transformation process and the individual ICT projects and acts of project management have been distinguished and elaborated (Melin and Wihlborg, 2018). This research draws on this initiative and enhances understanding of how the ICT project management and e-government transformation can be integrated through project governance practices. The targets set for government digitalization can be connected to ICT projects through forming a concrete digitalization strategy to align and prioritize projects within portfolios, which can also enable the control and balancing functions. This study also highlights the gaps between current academic discussions on governance mechanisms in a specific contextual setting, thus providing new insights into both e-government and governance research. The findings of this research suggest that governance can also be perceived from technical and delivery method standpoints, besides the commonly used organizational and process perspectives, thus bridging the current gap between ICT and project management research (Joslin and Müller, 2016b; Müller and Martinsuo, 2015).

The governance of public sector digitalization and projects seem to struggle with one underlying dilemma: To govern and align individual ICT projects with the national digitalization effort would require more than just operational level technological and mechanical ICT project governance practices. There is also a need for capability and willingness to govern also the higher-level social, economic and political elements such as processes and organization structures towards citizen and service centric transformation, as proposed for example in the classical NPM models (Cordella and Bonina, 2012). Instead of relying on governance through the traditional organizational silos, the focus should change toward governing the more effective citizen or entrepreneur service processes - bearing in mind of course the administrative restrictions or substance contextualities, such as in the defense sector, for example (Gilchrist et al., 2018). To synthesize the findings of this particular research, the following policy implications on governance and PMM on different organizational levels are proposed in Table IV.

Besides the addressed research scope limitations, this research has several more limitations to discuss. First, as a qualitative case study, drawing generalizable implications is impossible; however, this was not an aim of this research. Second, the data were limited to four public cases and publicly accessible documents; drawing reliable conclusions on such a sample is limited. Third, the research was subject to both respondent and researcher bias; the former were mitigated with supportive material and multiple respondents' presence when possible and the latter through rigorous triangulation among research and respondents (Yin, 2013). Fourth, as Finland is regarded as one of the most advanced nations in the utilization of digital solutions, the managerial implications provided in this study should be considered restricted and without international comparison; no definite conclusions should be made. 
Organizational level in government digitalization Project governance practices

STRATEGIC LEVEL: One comprehensive single law to cover

Political and regulatory governance system

\section{4} digitalization and ICT development (projects) that mandates and requires compliance
Explicit digitalization strategy over government terms that consists of vision, mission and roadmap based on current state analysis

Governance model updated to start from strategic level, including stakeholder management

EXECUTIVE LEVEL: $\quad$ Budgeting process streamlined, more Management system flexible, and investment oriented toward projects

Strong "linking pin" or Government CIO (JulkICT) to oversee common ICT project governance, including sourcing Only organizations with institutional legitimacy and power must participate in governance

Central PMO to oversee general project capability management, substance competence in administrative sectors (ministries, agencies)

Main technological elements governed and enforced centrally: Architecture, interoperability and Data

OPERATIONAL LEVEL: ICT Projects

Project owner owns project and benefits through lifecycle

Metrics and incentives for ICT projects and digitalization

Audits as inputs to roadmaps with responsibilities

Different project delivery types

conceptualized and supported

Use of project tools and best practices synchronized and shared
PPM assurance practices

Master portfolio included in roadmap

Parliament and public communication through portfolio Master portfolio targets and categories derived from national strategy

Master portfolio to include A Cross-organizational/significant projects ("SPECIAL cases"), and B - organizational (ministry, agency level) sub-portfolio status. Value perspective added Master portfolio categorizes, prioritizes and balances (objectives for) A - significant projects, and B Organizational sub-portfolios All ICT projects are included in, and budgeted and resourced through a portfolio (Master and/or organizational)

A formal process also for (Master) portfolio control that includes risk management and interoperability review, scalable for agency level A portfolio is only reporting and measurement format and reporting is done only once

Metrics and incentives for ICT project and portfolio performance Constant assessment of project deliverables

Business case and statement process made scalable to all project sizes and types

This research opened doors for many interesting research opportunities. First, an interesting topic for future research would be to assess how governable the public sector digitalization and the key actors in it are (Müller et al., 2014) and how this could be perceived in maturity aspects of e-government (Andersen and Henriksen, 2006; Esteves and Joseph, 2008). Second, as discussed, a comparative study of the synthesized findings between similar studies from other countries or through a literature review would reveal how broadly applicable or specific to Finland the results are. Third, a longitudinal participation or observation research - simultaneously, by multiple cross-disciplinary researchers, if possible - through different cases (organizations, projects) would validate 
the findings of this research and bring insight into underlying institutional mechanisms this study did not address thoroughly. Fourth, drawing further from institution theory, specifically institutional entrepreneurship (Maguire et al., 2004; Wijen and Ansari, 2007), an interesting research topic would be to study the performance and activities of the central actor as the active agent or "institutional entrepreneur hero" (Micelotta $e$ t al., 2017) of institutional change: digitalization. Finally, studying the processes of transitioning from strategic alignment to social alignment (Gilchrist et al., 2018) and forming and building a consensus of the national digitalization strategy (Bowman and Ambrosini, 1997; Floyd and Wooldridge, 1992; OECD, 2014) could also provide valuable insight into the topic.

\section{References}

Altameem, T., Zairi, M. and Alshawi, S. (2006), "Critical success factors of E-Government: a proposed model for E-Government implementation”, 2006 Innovations in Information Technology, pp. 1-5.

Andersen, E.S. (2015), "Illuminating the role of the project owner", International Journal of Managing Projects in Business, Vol. 5 No. 1, pp. 67-85.

Andersen, K.V. and Henriksen, H.Z. (2006), "E-government maturity models: extension of the Layne and lee model", Government Information Quarterly, Vol. 23 No. 2, pp. 236-248.

Anthopoulos, L. and Fitsilis, P. (2014), "Trends in e-Strategic management: how do governments transform their policies?", International Journal of Public Administration in the Digital Age, Vol. 1 No. 1, pp. 15-38.

Archer, N. and Ghasemzadeh, F. (1999), "An integrated framework for project portfolio selection", International Journal of Project Management, Vol. 17 No. 4, pp. 207-216.

Arnaboldi, M., Azzone, G. and Savoldelli, A. (2004), "Managing a public sector project: the case of the Italian treasury ministry", International Journal of Project Management, Vol. 22 No. 3, pp. 213-223.

Asgarkhani, M. (2005), "Digital government and its effectiveness in public management reform: a local government perspective", Public Management Review, Vol. 7 No. 3, pp. 465-487.

Biesenthal, C. and Wilden, R. (2014), "Multi-level project governance: trends and opportunities", International Journal of Project Management, Vol. 32 No. 8, pp. 1291-1308.

Blichfeldt, B.S. and Eskerod, P. (2008), "Project portfolio management - there's more to it than what management enacts", International Journal of Project Management, Vol. 26 No. 4, pp. 357-365.

Bowman, C. and Ambrosini, V. (1997), "Perceptions of strategic priorities, consensus and firm performance”, Journal of Management Studies, Vol. 34 No. 2, pp. 241-258.

Bridges, D.N. (1999), "Project portfolio management: ideas and practices", in Dye, L.D. and Pennypacker, J.S. (Eds), Project Portfolio Management-Selecting and Prioritizing Projects for Competitive Advantage, 1st ed., Center for Business Practices, West Chester, PA, pp. 45-54.

Brunet, M. (2018), “Governance-as-practice for major public infrastructure projects: a case of multilevel project governing", International Journal of Project Management, Elsevier Ltd and Association for Project Management and the International Project Management Association.

Cooper, R.G. (2008), "Perspective: the Stage-Gates idea-to-Launch process - update, what's new, and NexGen systems”, Journal of Product Innovation Management, Vol. 25 No. 3, pp. 213-232.

Cordella, A. and Bonina, C.M. (2012), "A public value perspective for ICT enabled public sector reforms: a theoretical reflection", Government Information Quarterly, Vol. 29 No. 4, pp. 512-520.

Cordella, A. and Tempini, N. (2015), "E-government and organizational change: reappraising the role of ICT and bureaucracy in public service delivery", Government Information Quarterly, Vol. 32 No. 3, pp. 279-286. 
Crawford, L.H. and Helm, J. (2009), "Government and governance: the value of project management in the public sector", Project Management Journal, Vol. 40 No. 1, pp. 73-87.

DeFillippi, R. and Sydow, J. (2016), "Project networks: governance choices and paradoxical tensions", Project Management Journal, Vol. 47 No. 5, pp. 1-12.

de Haes, S. and van Grembergen, W. (2009), "An exploratory study into IT governance implementations and its impact on business/IT alignment", Information Systems Management, Vol. 26 No. 2, pp. 123-137.

de Reyck, B., Grushka-Cockayne, Y., Lockett, M., Calderini, S.R., Moura, M. and Sloper, A. (2005), "The impact of project portfolio management on information technology projects", International Journal of Project Management, Vol. 23 No. 7, pp. 524-537.

Drury, M., Conboy, K. and Power, K. (2012), "Obstacles to decision making in agile software development teams", Journal of Systems and Software, Vol. 85 No. 6, pp. 1239-1254.

Dye, L.D. and Pennypacker, J.S. (Eds) (1999), Project Portfolio Management: Selecting and Prioritizing Projects for Competitive Advantage, 1st ed., Center for Business Practices, West Chester, PA.

Eisenhardt, K.M. (1989), "Building theories from case study research", Academy of Management Review, Vol. 14 No. 4, pp. 532-550.

Esteves, J. and Joseph, R.C. (2008), "A comprehensive framework for the assessment of eGovernment projects”, Government Information Quarterly, Vol. 25 No. 1, pp. 118-132.

Fishenden, J. and Thompson, M. (2013), "Digital government, open architecture, and innovation: why public sector it will never be the same again", Journal of Public Administration Research and Theory, Vol. 23 No. 4, pp. 977-1004.

Floyd, S.W. and Wooldridge, B. (1992), "Managing strategic consensus: the foundation of effective implementation", Academy of Management Perspectives, Vol. 6 No. 4, pp. 27-39.

Gil-Garcia, J.R. and Martinez-Moyano, I.J. (2007), "Understanding the evolution of e-government: the influence of systems of rules on public sector dynamics", Government Information Quarterly, Vol. 24 No. 2, pp. 266-290.

Gilchrist, A., Burton-Jones, A. and Green, P. (2018), “The process of social alignment and misalignment within a complex IT project", International Journal of Project Management, Vol. 36 No. 6, pp. 845-860.

Hansen, L.K. and Kræmmergaard, P. (2013), "Transforming local government by project portfolio management: identifying and overcoming control problems", Transforming Government: People, Process and Policy, Vol. 7 No. 1, pp. 50-75.

Hrebiniak, L.G. and Joyce, W.F. (1984), Implementing Strategy, 1st ed., MacMillan, New York, NY.

Irani, Z.E.Z. (2005), "E-government adoption: architecture and barriers", Business Process Management Journal, Vol. 11 No. 5, pp. 589-611.

Janowski, T. (2015), "Digital government evolution: from transformation to contextualization (editorial)", Government Information Quarterly, Vol. 32 No. 3, pp. 221-236.

Janssen, M. and Klievink, B. (2012), "Can enterprise architectures reduce failure in development projects?", Transforming Government: People, Process and Policy, Vol. 6 No. 1, pp. $27-40$.

Janssen, M. and van der Voort, H. (2016), "Adaptive governance: towards a stable, accountable and responsive government”, Government Information Quarterly, Vol. 33 No. 1, pp. 1-5.

Jenner, S. (2010), Transforming Government and Public Services: Realising Benefits through Project Portfolio Management, Gower, Farnham.

Johnson-Laird, P.N. (1999), “Deductive reasoning”, Annual Review of Psychology, Vol. 50, pp. 109-135.

Jonas, D. (2010), "Empowering project portfolio managers: how management involvement impacts project portfolio management performance", International Journal of Project Management, Vol. 28 No. 8, pp. 818-831. 
Joslin, R. and Müller, R. (2016a), "The relationship between project governance and project success", International Journal of Project Management, Vol. 34 No. 4, pp. 613-626.

Joslin, R. and Müller, R. (2016b), "The impact of project methodologies on project success in different project environments", International Journal of Managing Projects in Business, Vol. 9 No. 2, pp. 364-388.

Kaiser, M.G., El Arbi, F. and Ahlemann, F. (2015), "Successful project portfolio management beyond project selection techniques: understanding the role of structural alignment", International Journal of Project Management, Vol. 33 No. 1, pp. 126-139.

Kathuria, R., Joshi, M.P. and Porth, S.J. (2007), "Organizational alignment and performance: past, present and future", Management Decision, Vol. 45 No. 3, pp. 503-517.

Ketokivi, M. and Choi, T. (2014), "Renaissance of case research as a scientific method", Journal of Operations Management, Vol. 32 No. 5, pp. 232-240.

Lahdenperä, P. (2012), "Making sense of the multi-party contractual arrangements of project partnering, project alliancing and integrated project delivery", Construction Management and Economics, Vol. 30 No. 1, pp. 57-79.

Lappi, T. and Aaltonen, K. (2017), "Project governance in public sector agile software projects", International Journal of Managing Projects in Business, Vol. 10 No. 2, pp. 263-294.

Layne, K. and Lee, J. (2001), "Developing a fully functional E-government: a four stage model", Government Information Quarterly, Vol. 18 No. 2, pp. 122-136.

Lee, J. (2010), "10year retrospect on stage models of e-Government: a qualitative Meta-synthesis", Government Information Quarterly, Vol. 27 No. 3, pp. 220-230.

Loorbach, D. (2010), "Transition management for sustainable development: a prescriptive, complexitybased governance framework", Governance, Vol. 23 No. 1, pp. 161-183.

Love, P.E.D., Mistry, D. and Davis, P.R. (2010), "Price competitive alliance projects: identification of success factors for public clients", Journal of Construction Engineering and Management, Vol. 136 No. 9, pp. 947-956.

Lundin, R.A., Söderholm, A. and Soderholm, A. (1995), "A theory of the temporary organization", Scandinavian Journal of Management, Vol. 11 No. 4, pp. 437-455.

McElroy, W. (1996), "Implementing strategic change through projects", International Journal of Project Management, Vol. 14 No. 6, pp. 325-329.

McGrath, S.K. and Whitty, S.J. (2015), "Redefining governance: from confusion to certainty and clarity", International Journal of Managing Projects in Business, Vol. 8 No. 4, pp. 755-787.

MacDonald, C., Walker, D.H.T. and Moussa, N. (2012), "Value for money in project alliances", International Journal of Managing Projects in Business, Vol. 5 No. 2, pp. 311-324.

Maguire, S., Hardy, C. and Lawrence, T.B. (2004), "Institutional entrepreneurship in emerging fields: HIV/AIDS treatment advocacy in Canada", The Academy of Management Journal, Vol. 47 No. 5 , pp. 657-679.

Marnewick, C. (2016), "Benefits of information system projects: the tale of two countries", International Journal of Project Management, Vol. 34 No. 4, pp. 748-760.

Marnewick, C. and Labuschagne, L. (2011), "An investigation into the governance of information technology projects in South Africa”, International Journal of Project Management, Vol. 29 No. 6, pp. 661-670.

Martinsuo, M. and Dietrich, P. (2002), "Public sector requirements towards project portfolio management”, $P M I{ }^{\circledR}$ Research Conference 2002: Frontiers of Project Management Research and Applications, Project Management Institute, Newtown Square, PA.

Martinsuo, M. and Lehtonen, P. (2007), "Role of single-project management in achieving portfolio management efficiency", International Journal of Project Management, Vol. 25 No. 1, pp. 56-65. 
Melin, U. and Wihlborg, E. (2018), "Balanced and integrated e-government implementation - exploring the crossroad of public policy-making and information systems project management processes", Transforming Government: People, Process and Policy, Vol. 12 No. 2, pp. 191-208.

Meskendahl, S. (2010), "The influence of business strategy on project portfolio management and its success - A conceptual framework", International Journal of Project Management, Vol. 28 No. 8, pp. 807-817.

Micelotta, E., Lounsbury, M. and Greenwood, R. (2017), "Pathways of institutional change: an integrative review and research agenda", Journal of Management, Vol. 43 No. 6, pp. 1885-1910.

Mosavi, A. (2014), "Exploring the roles of portfolio steering committees in project portfolio governance", International Journal of Project Management, Vol. 32 No. 3, pp. 388-399.

Müller, R. (2009), Project Governance, Gower, Farnham.

Müller, R. and Martinsuo, M. (2015), "The impact of relational norms on information technology project success and its moderation through project governance", International Journal of Managing Projects in Business, Vol. 8 No. 1, pp. 154-176.

Müller, R., Martinsuo, M. and Blomquist, T. (2008), "Project portfolio control and portfolio management performance in different contexts", Project Management Journal, Vol. 39 No. 3, pp. 28-42.

Müller, R., Pemsel, S. and Shao, J. (2014), "Organizational enablers for governance and governmentality of projects: a literature review”, International Journal of Project Management, Vol. 32 No. 8, pp. 1309-1320.

Nielsen, J.A. and Pedersen, K. (2014), "IT portfolio decision-making in local governments: rationality, politics, intuition and coincidences", Government Information Quarterly, Vol. 31 No. 3, pp. 411-420.

Nuottila, J., Aaltonen, K. and Kujala, J. (2016), "Challenges of adopting agile methods in a public organization", International Journal of Information Systems and Project Management, Vol. 4 No. 3, pp. 65-85.

Oakes, G. (2008), Project Reviews, Assurance and Governance, Gower, Aldershot.

OECD (2014), Recommendation of the Council on Digital Government Strategies, OECD, Paris.

OECD (2015), OECD Public Governance Reviews: Estonia and Finland: Fostering Strategic Capacity across Governments and Digital Services across Borders, OECD, Paris.

Olsson, N.O.E., Johansen, A., Langlo, J.A. and Torp, O. (2008), "Project ownership: implications on success measurement”, Measuring Business Excellence, Vol. 12 No. 1, pp. 39-46.

Omar, A., Weerakkody, V. and Sivarajah, U. (2017), "Digitally enabled service transformation in UK public sector: a case analysis of universal credit", International Journal of Information Management, Vol. 37 No. 4, pp. 350-356.

Papp, R. (1999), "Business-IT alignment: productivity paradox payoff?", Industrial Management and Data Systems, Vol. 99 No. 8, pp. 367-373.

Pedersen, K. (2018), "E-government transformations: challenges and strategies", Transforming Government: People, Process and Policy, Vol. 12 No. 1, pp. 84-109.

Petro, Y. and Gardiner, P. (2015), "An investigation of the influence of organizational design on project portfolio success, effectiveness and business efficiency for project-based organizations", International Journal of Project Management, Vol. 33 No. 8, pp. 1717-1729.

Rorissa, A., Demissie, D. and Pardo, T. (2011), "Benchmarking e-Government: a comparison of frameworks for computing e-Government index and ranking", Government Information Quarterly, Vol. 28 No. 3, pp. 354-362.

Ruuska, I., Ahola, T., Artto, K., Locatelli, G. and Mancini, M. (2011), "A new governance approach for multi-firm projects: lessons from Olkiluoto 3 and flamanville 3 nuclear power plant projects", International Journal of Project Management, Vol. 29 No. 6, pp. 647-660. 
Samset, K. and Volden, G.H. (2016), "Front-end definition of projects: ten paradoxes and some reflections regarding project management and project governance", International Journal of Project Management, Vol. 34 No. 2, pp. 297-313.

Sanderson, J. (2012), "Risk, uncertainty and governance in megaprojects: a critical discussion of alternative explanations", International Journal of Project Management, Vol. 30 No. 4, pp. 432-443.

Sarker, S., Xiao, X. and Beaulieu, T. (2013), "Qualitative studies in information systems: a critical review and some guiding principles", MIS Quarterly, Vol. 37 No. 4, pp. 3-18.

Scott, W.R. (2013), Institutions and Organizations: Ideas, Interests, and Identities, 4th ed., Sage Publications, Thousand Oaks, CA.

Serra, C.E.M. and Kunc, M. (2014), "Benefits realisation management and its influence on project success and on the execution of business strategies", International Journal of Project Management, Vol. 33 No. 1, pp. 53-66.

Snead, J.T. and Wright, E. (2014), "E-government research in the United States", Government Information Quarterly, Vol. 31 No. 1, pp. 129-136.

Srivannaboon, S. and Milosevic, D.Z. (2006), "A two-way influence between business strategy and project management”, International Journal of Project Management, Vol. 24 No. 6, pp. 493-505.

Stewart, R.A. (2008), “A framework for the life cycle management of information technology projects: ProjectIT”, International Journal of Project Management, Vol. 26 No. 2, pp. 203-212.

Too, E.G. and Weaver, P. (2013), "The management of project management: a conceptual framework for project governance", International Journal of Project Management, Vol. 32 No. 8, pp. 1382-1394.

Turner, J.R. (2006), "Towards a theory of project management: the nature of the project governance and project management", International Journal of Project Management, Vol. 24 No. 2, pp. 93-95.

Unger, B.N., Gemünden, H.G. and Aubry, M. (2012), “The three roles of a project portfolio management office: their impact on portfolio management execution and success", International Journal of Project Management, Vol. 30 No. 5, pp. 608-620.

Vainio, A., Viinamäki, O., Pitkänen, S. and Paavola, J.-M. (2017), "Public services - international comparison", available at: http://tietokayttoon.fi/julkaisu?pubid=21601

Valdés, G., Solar, M., Astudillo, H., Iribarren, M., Concha, G. and Visconti, M. (2011), "Conception, development and implementation of an e-Government maturity model in public agencies", Government Information Quarterly, Vol. 28 No. 2, pp. 176-187.

Vlietland, J., Van Solingen, R. and Van Vliet, H. (2016), "Aligning codependent scrum teams to enable fast business value delivery: a governance framework and set of intervention actions", Journal of Systems and Software, Vol. 113, pp. 418-429.

Walser, K. (2013), "IT project governance - why IT projects in public administration fail and what can be done about it", European Conference on E-Government, Academic Conferences International Limited, Kidmore End, pp. 543-550.

Wijen, F. and Ansari, S. (2007), "Overcoming inaction through collective institutional entrepreneurship: insights from regime theory", Organization Studies, Vol. 28 No. 7, pp. 1079-1100.

Winch, G.M. (2014), “Three domains of project organising”, International Journal of Project Management, Vol. 32 No. 5, pp. 721-731.

Yin, R.K. (2013), Case Study Research: Design and Methods, SAGE Publications, Thousand Oaks, CA. 
TG

13,2

190

\section{Appendix}

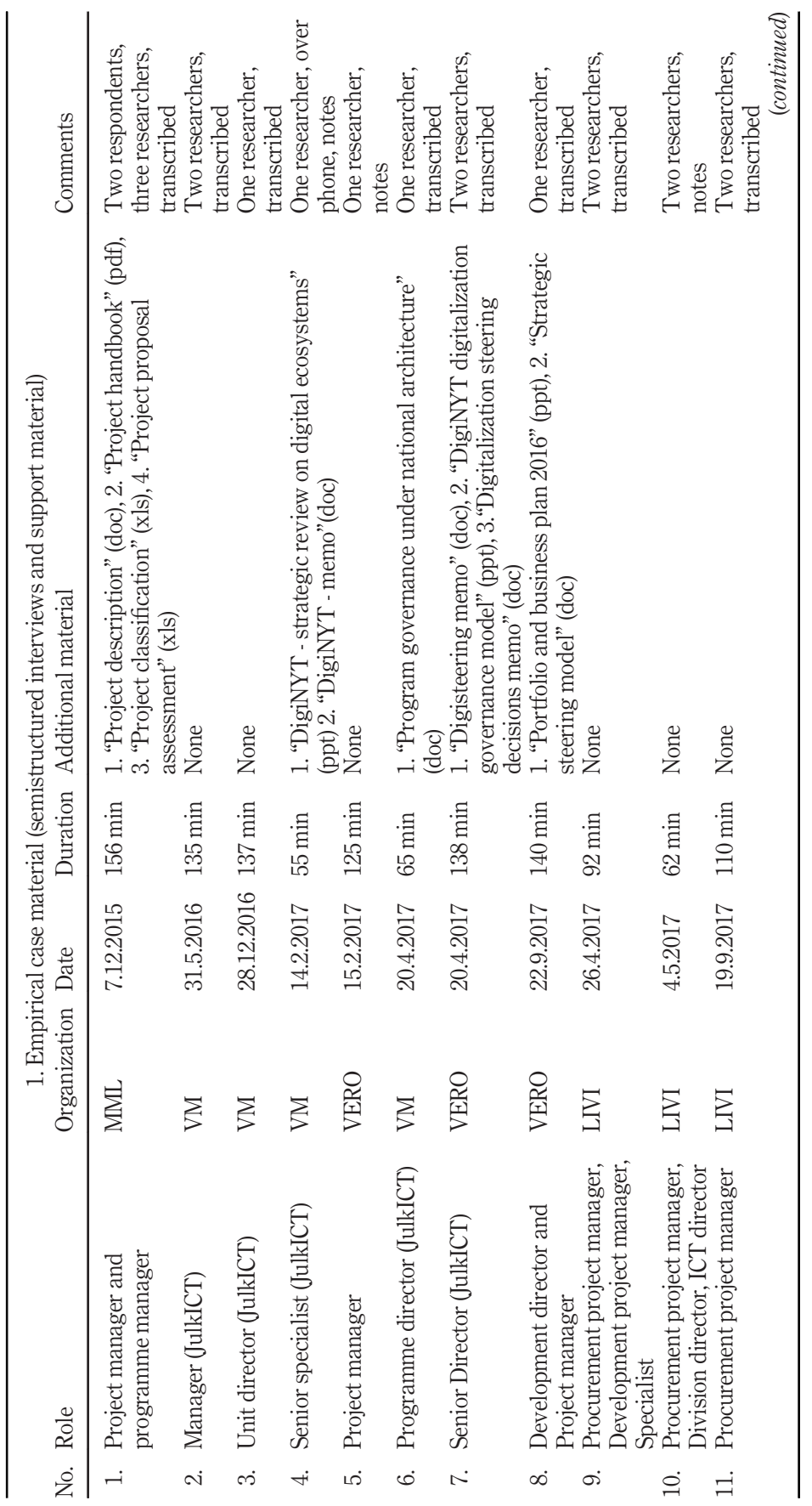

Table AI.

Acquired research data details

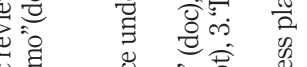

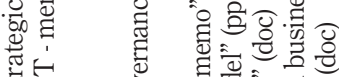

क它 它

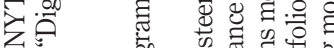
500 50 50 50 告

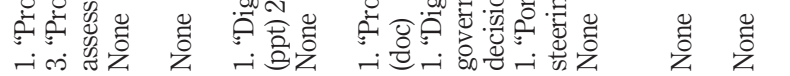

I 

TG

13,2

192

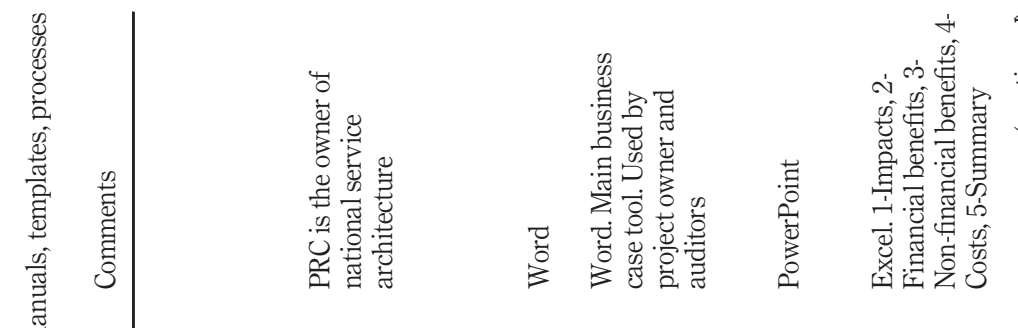

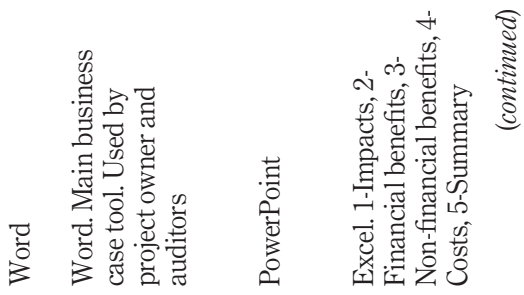

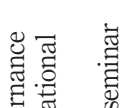

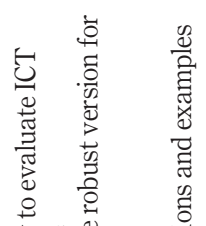

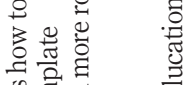

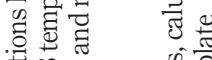

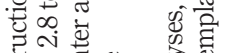

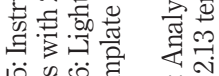

ம்

ชิ

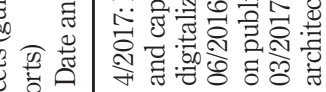

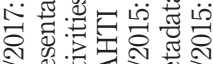

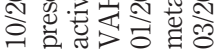

ठำ $N$ 包

范 范

จ จ ลิ

$N \quad-N$

$\sim N$

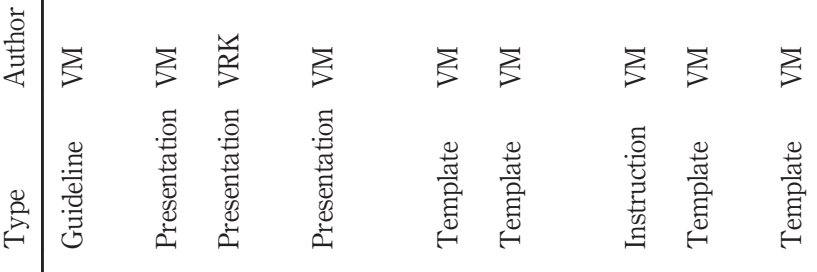

氖

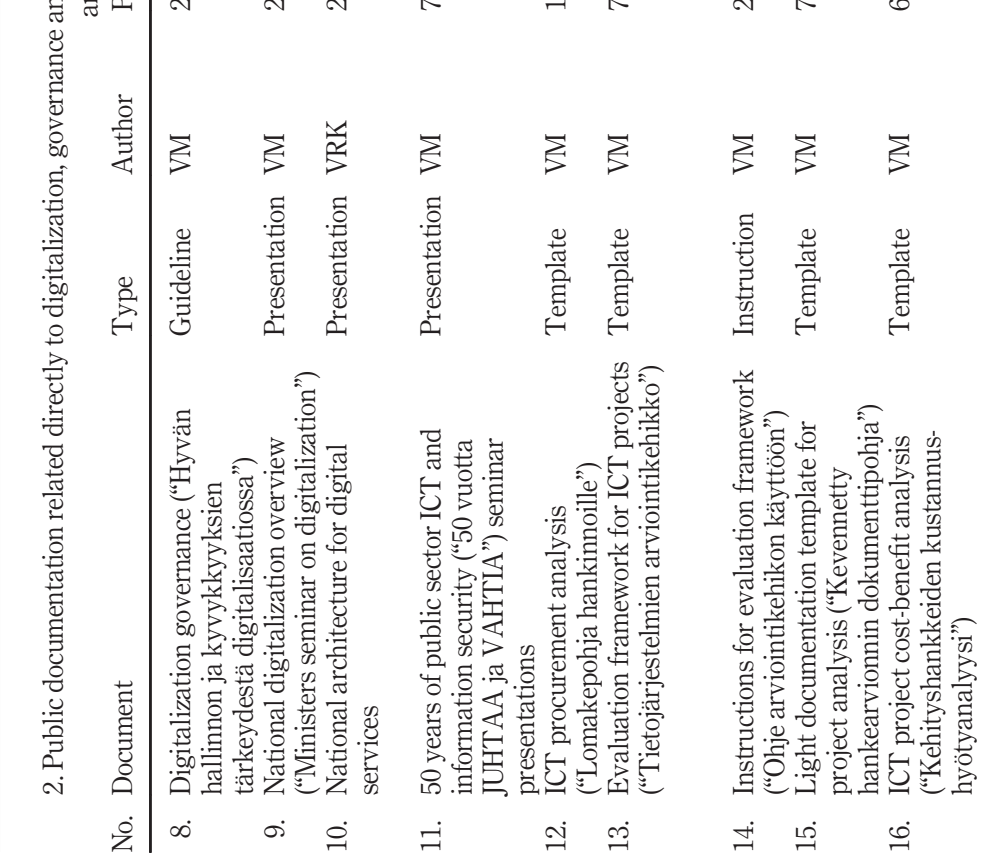

Table AI. 

TG

13,2

194

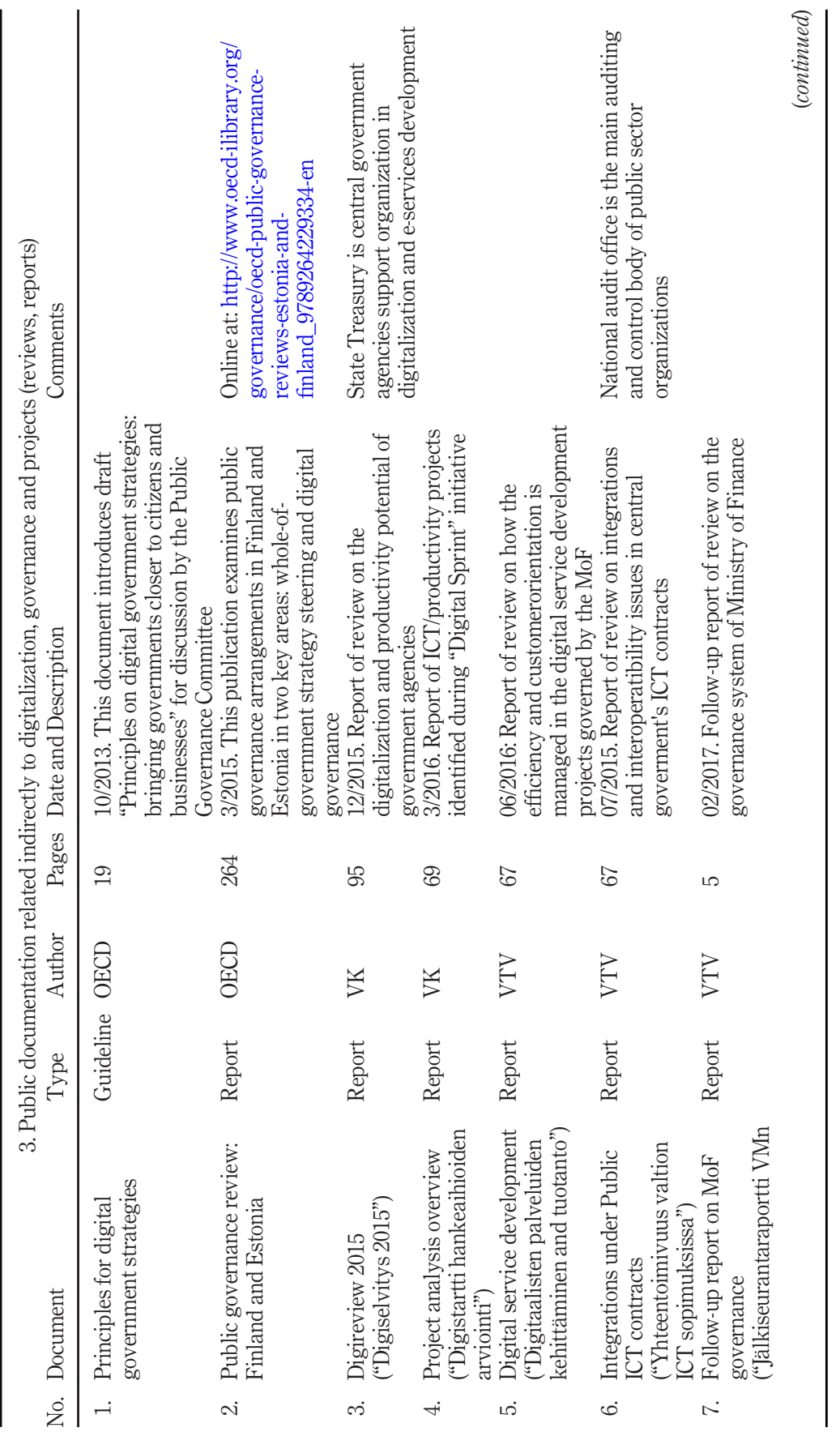

Table AI. 


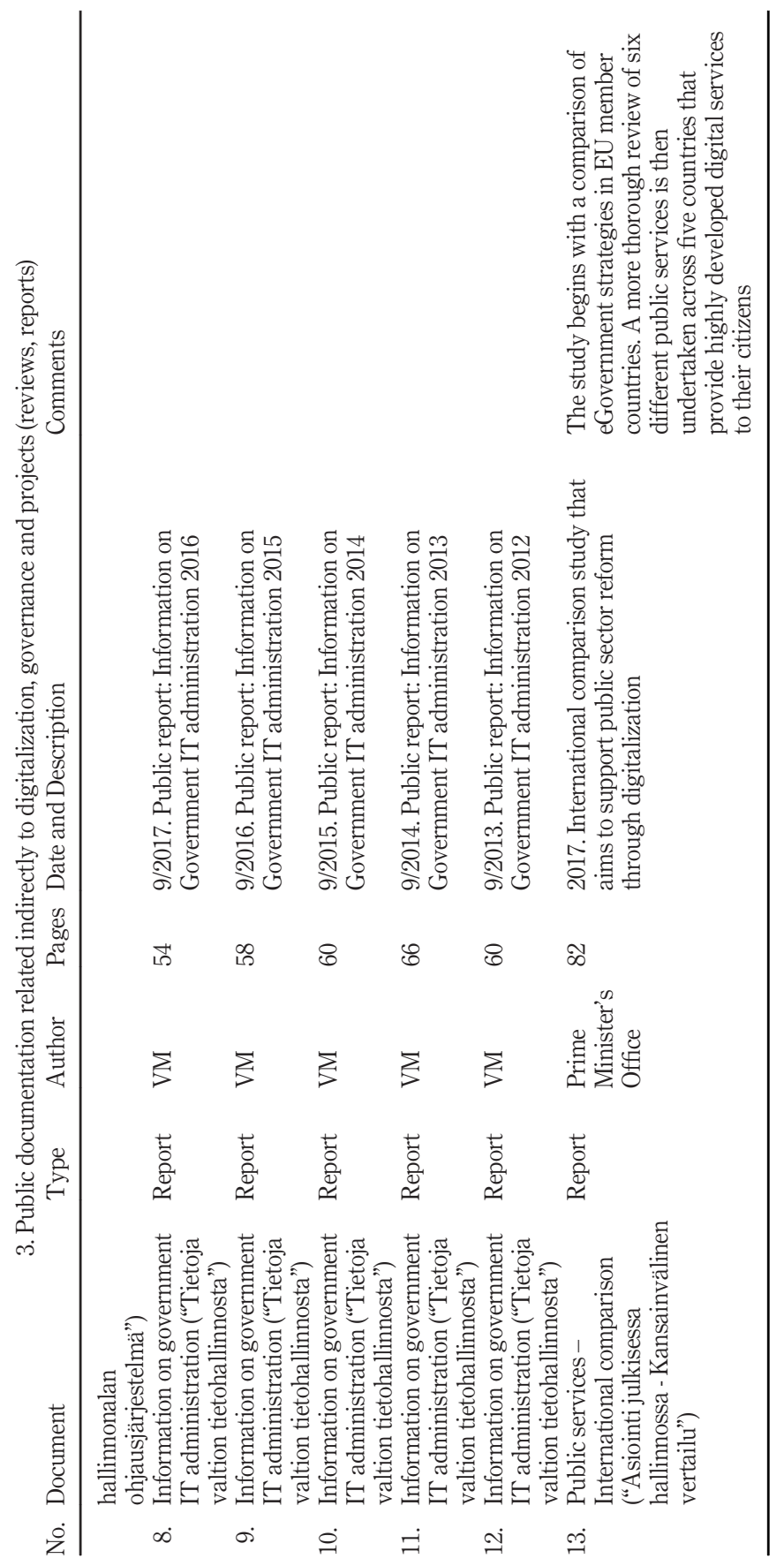

Project

governance

195

Table AI. 


\section{About the authors}

Teemu Mikael Lappi (M.Sc) is a doctoral student, researcher and a Lecturer in the Industrial Engineering and Management research unit at University of Oulu, Finland. Lappi received his master's degree in Industrial Engineering and Management at University of Oulu in 2004. He has worked for 13 years in various specialist and management positions in manufacturing and software industries, most recently as Business Development Director in a multinational software solution company. Lappi's dissertation topic and research interests include project governance, project business management, information systems, agile and e-government. Teemu Mikael Lappi is the corresponding author and can be contacted at: teemu.lappi@oulu.fi

Dr Kirsi Aaltonen is an Associate Professor of Project Management at University of Oulu, Industrial Engineering and Management research unit and Docent of Project Business at Aalto University, Industrial Engineering and Management. Her current research interests are in areas of governance, stakeholder and uncertainty management in large and complex projects. Her publication list includes more than 50 academic papers and book chapters in the area of project business. Aaltonen has published for example in Scandinavian Journal of Management, International Journal of Project Management, International Journal of Production and Operations Management, Project Management Journal and International Journal of Managing Projects in Business.

Dr Jaakko Kujala is a Professor in Industrial Engineering and Management research unit at the University of Oulu, Finland. He has over 10 years' experience in industry while working in international automation system project business before his career in the academia. His publications include more than 100 academic papers, book chapters and books on project business and on the management of project-based firms. His current research interests include coordination of complex project networks, stakeholder management and simulation as a research method.

For instructions on how to order reprints of this article, please visit our website: www.emeraldgrouppublishing.com/licensing/reprints.htm Or contact us for further details: permissions@emeraldinsight.com 